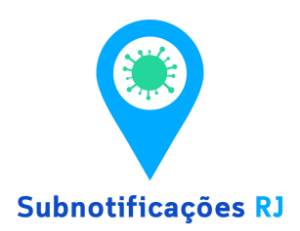

\title{
Relatório Subnotificados 2020 COVID-19 - Estado do Rio de Janeiro
}

Maria Isabel de Castro de Souza ${ }^{\text {a }}$, (D) Alexandre Sztajnberg ${ }^{\text {a }}$, (D) Fabiano Saldanha Gomes de Oliveira ${ }^{\text {a }}$ Jerson L. Silva b, c, (D) José Augusto Sapienza Ramos a , (D) Karla Figueiredo a , (D) Lisandro Lovisolo ${ }^{\text {, }}$ (I) Luiz Otavio de Azevedo d, (D) Roberto Medronho b, (D) Fabio Henrique Cardoso a , (D) Gabrielle da Silva Pereira ${ }^{\text {, }}$ (D) Wellington Rodrigo de Freitas Costa ${ }^{\text {a }}$

a Universidade do Estado do Rio de Janeiro

b Universidade Federal do Rio de Janeiro

${ }^{\mathrm{c}}$ Fundação Carlos Chagas Filho de Amparo à Pesquisa do Estado do Rio de Janeiro

d Fundação Oswaldo Cruz

Correspondência: profamariaisabel@yahoo.com.br; alexszt@ime.uerj.br, fgomes@ims.uerj.br, jerson@bioqmed.ufrj.br, sapienza@labgis.uerj.br, karlafigueiredo@ime.uerj.br, lisandro@uerj.br, medronho@medicina.ufrj.br

Rio de Janeiro, 15 de Julho de 2020

Sugestão de citação:

M.I. Souza, et al. Relatório Subnotificados 2020 COVID-19 - Estado do Rio de Janeiro, 15 de Julho de 2020. Subnotificações RJ COVID 2020. DOI: https://doi.org/10.12957/eduerj.rjsubcovid19.relatorio1 
Este relatório está relacionado ao projeto "Aplicação de questionário digital para levantamento de casos de subnotificação da COVID-19 no estado do Rio de Janeiro (SUB-19)" inscrito na Plataforma Brasil e com parecer consubstanciado do CEP (31413020.9.0000.5259): a Subsecretaria de Estado de Ciência, Tecnologia e Inovação (SECTI), FAPERJ, UERJ, UFRJ e FIOCRUZ, sendo aprovada no Comitê de Ética em Pesquisa do Hospital Universitário Pedro Ernesto da UERJ (31413020.9.0000.5259/HUPE/UERJ). Além disso, todos os envolvidos comprometem-se a manter o sigilo das informações, conforme determina a Comissão Nacional de Ética em Pesquisa (CONEP) e a Lei Geral de Proteção de Dados (LGPD).

\section{Introdução}

Segundo o Ministério da Saúde1, a doença COVID-19, causada pelo SARS-CoV-2, possui amplo espectro clínico podendo apresentar-se desde uma infecção assintomática a formas graves que podem evoluir para o óbito. Entre os sintomas mais comuns estão a febre, tosse, coriza, dor de garganta e dificuldade de respirar.

O diagnóstico da COVID-19, realizado por profissional de saúde, deve considerar a presença em pacientes de dois critérios clínicos':

- Síndrome Gripal (quadro respiratório agudo): com sensação febril ou febre, que pode ou não estar presente na hora da consulta (podendo ser relatada ao profissional de saúde), acompanhada de tosse ou dor de garganta ou coriza ou dificuldade respiratória;

- Síndrome Respiratória Aguda Grave: com desconforto respiratório/dificuldade para respirar ou pressão persistente no tórax ou saturação de oxigênio menor que $95 \%$ em ar ambiente ou coloração azulada dos lábios ou rosto

O conhecimento da magnitude do processo pandêmico na população é fundamental para orientar as políticas públicas de prevenção e controle da doença. Além disso, pode orientar as medidas de afrouxamento do isolamento social, já que se espera que a doença produza proteção imunológica por um determinado período, mesmo que curto. Tal conhecimento deve levar em conta não apenas os casos notificados ao sistema de vigilância epidemiológica, mas também os casos assintomáticos que não foram detectados pelo sistema.

Este relatório traz os resultados da coleta dos dados a partir de questionário (no apêndice A) realizado por meio do sistema REDCap ${ }^{2}$, instalado na FIOCRUZ e disponibilizado no link: https://redcap.icict.fiocruz.br/surveys/index.php?s=WKHKEC8FWE.

A primeira parte do relatório descreverá detalhadamente os dados coletados no período entre 08/Maio/2020 e 04/Julho/2020 e a segunda parte tratará dos casos subnotificados para o mesmo período.

\section{Descrição dos dados coletados:}

A partir da Figura 1 pode-se observar a taxa de sincronização entre a captura do questionário no servidor Web na FIOCRUZ e a atualização do banco de dados na UERJ, a cada 500 questionários preenchidos. No período entre 16 de Maio e 04 de Julho, a ampla divulgação do questionário através de diferentes mídias (sites, rádio, televisão, Facebook, Instagram, WhatsApp) proporcionou um intenso preenchimento do mesmo, conforme caracterizado na Figura 1. 
Até o final do dia 04 de julho foram computados 33841 respondentes com CEP válido considerando qualquer região do país. Dentre esses, há 28926 respondentes do Estado do Rio de Janeiro e 4915 respondentes de outros estados do Brasil.

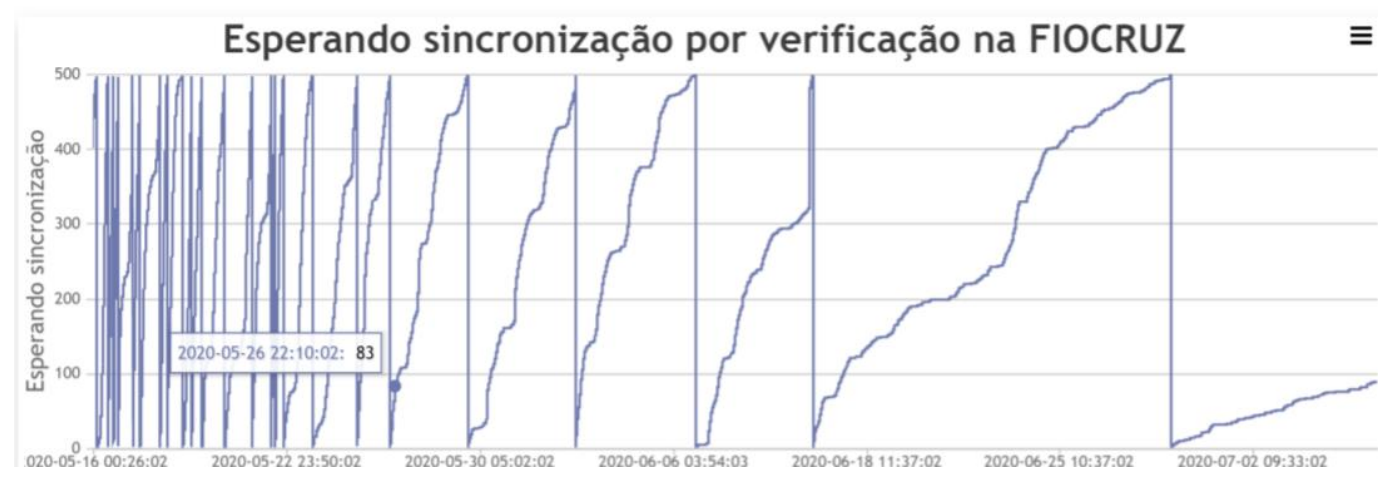

Figura 1 - Taxa de sincronização entre a captura do questionário e a transferência para o banco de dados.

A Figura 2 apresenta uma visão geral dos respondentes do questionário de subnotificação. O gráfico apresenta: (a) as proporções dos respondentes que responderam ter ou não apresentado algum sintoma; (b) as proporções de respondentes de acordo com suas declarações de sexo; (c) a proporções de respondentes que pertencem ou não ao estado do Rio de Janeiro; (d) as proporções dos respondentes com CPF válido ou não; (e) as proporções de respondentes do estado do Rio de Janeiro com CPF válido ou não e (f) as proporções dos respondentes que são ou não profissionais da área de saúde.

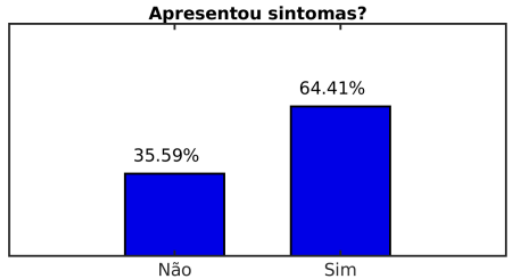

(a)

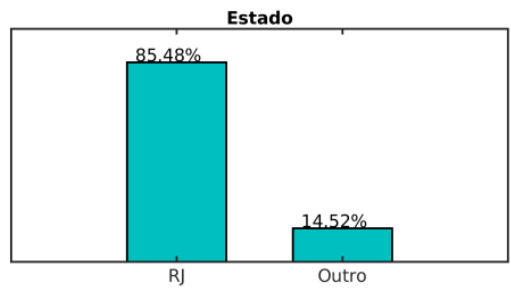

(c)

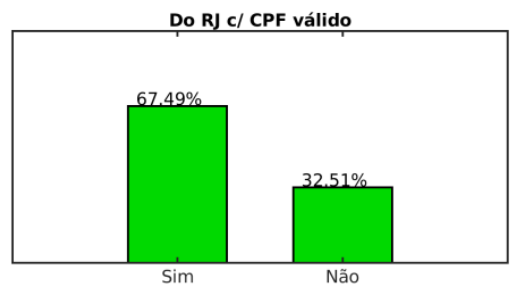

(e)

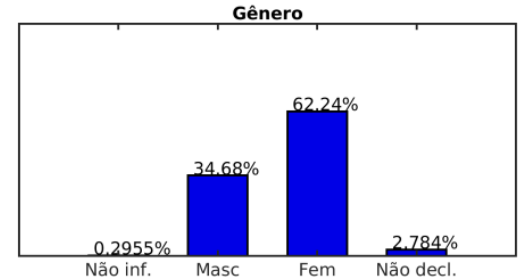

(b)

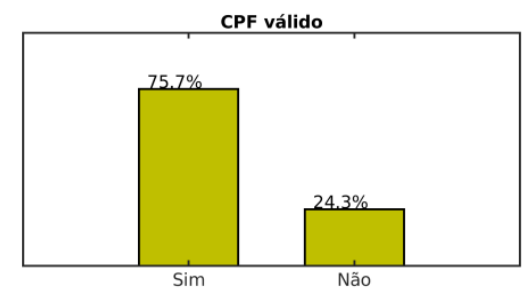

(d)

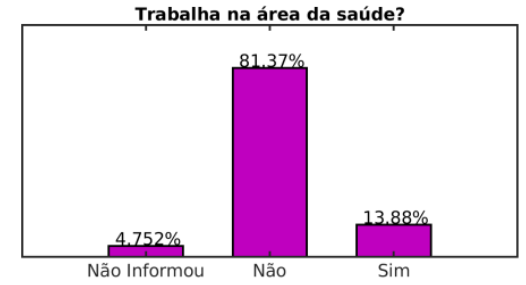

(f)

A Figura 3 mostra a proporção de respondentes que fizeram testes (a), o tipo de teste (b), se declararam o resultado (c) e qual foi o resultado obtido (d). 


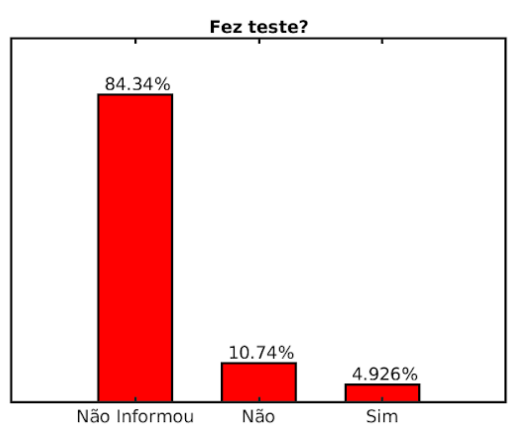

(a)

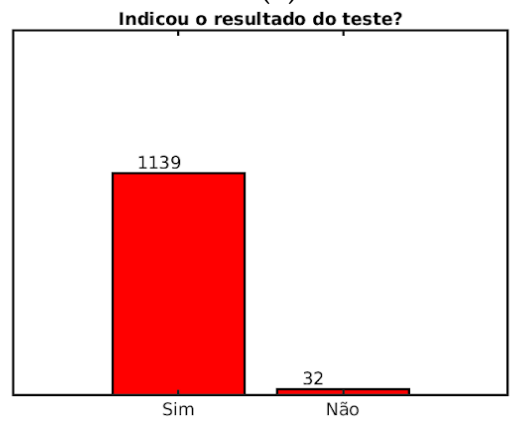

(c)

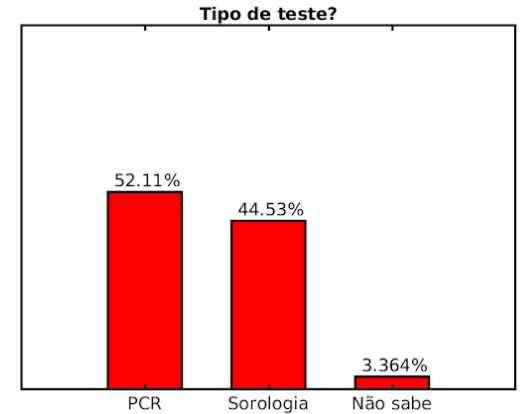

(b)

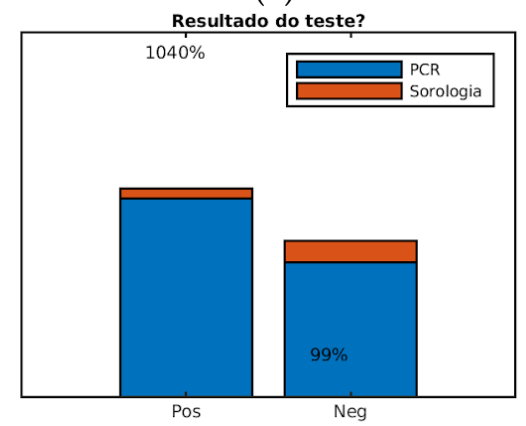

(d)

Figura 3 - Informações dos Testes

Através das Figuras 4 a 9 podemos observar as distribuições por gênero e faixa etária dos respondentes separadas por: todos os respondentes (Figura 4), respondentes do estado do Rio de Janeiro (Figura 5), respondentes com CPF válido (Figura 6), respondentes do estado do Rio de Janeiro e com CPF válido (Figura 7), respondentes que declararam ser profissionais da área de saúde (Figura 8) e respondentes que declaram terem sido testados (Figura 9).
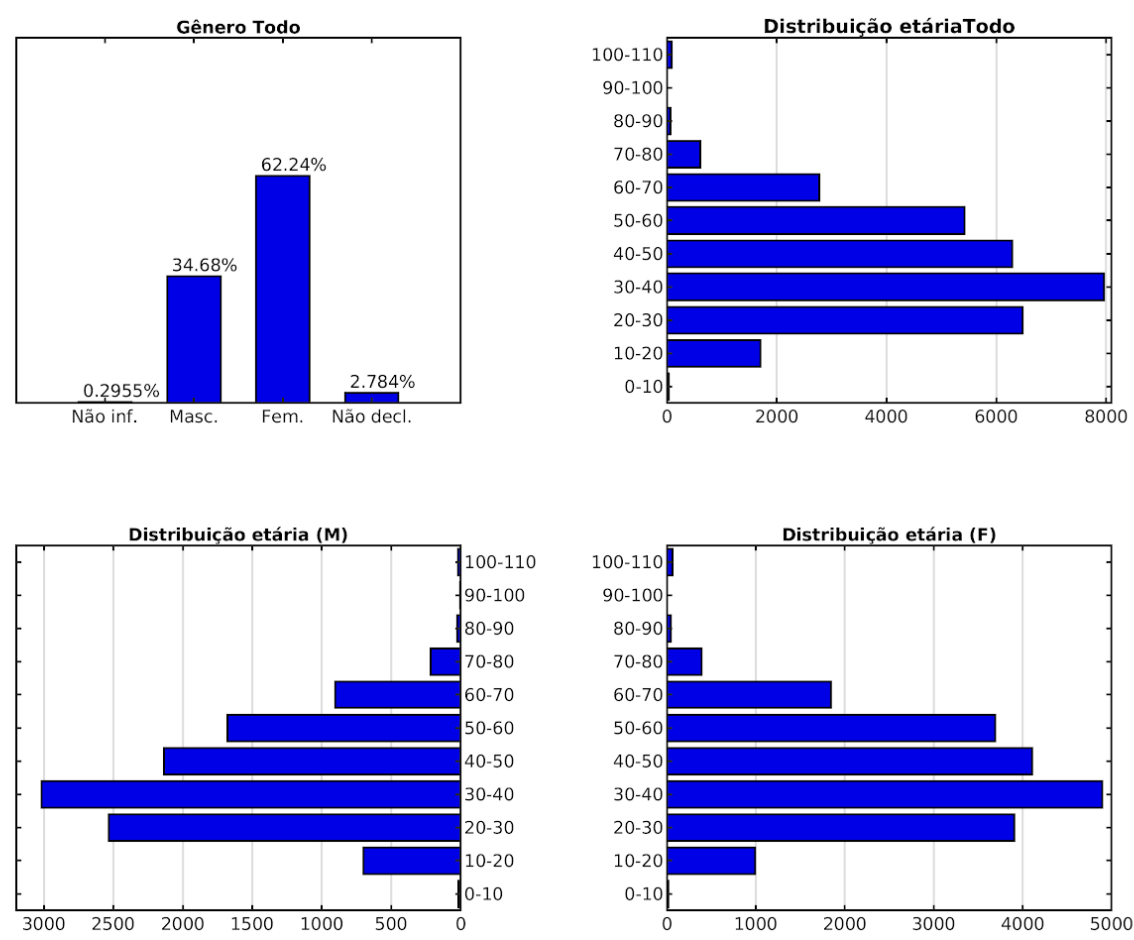

Figura 4 - Todos os Respondentes

(gênero e faixa etária) 

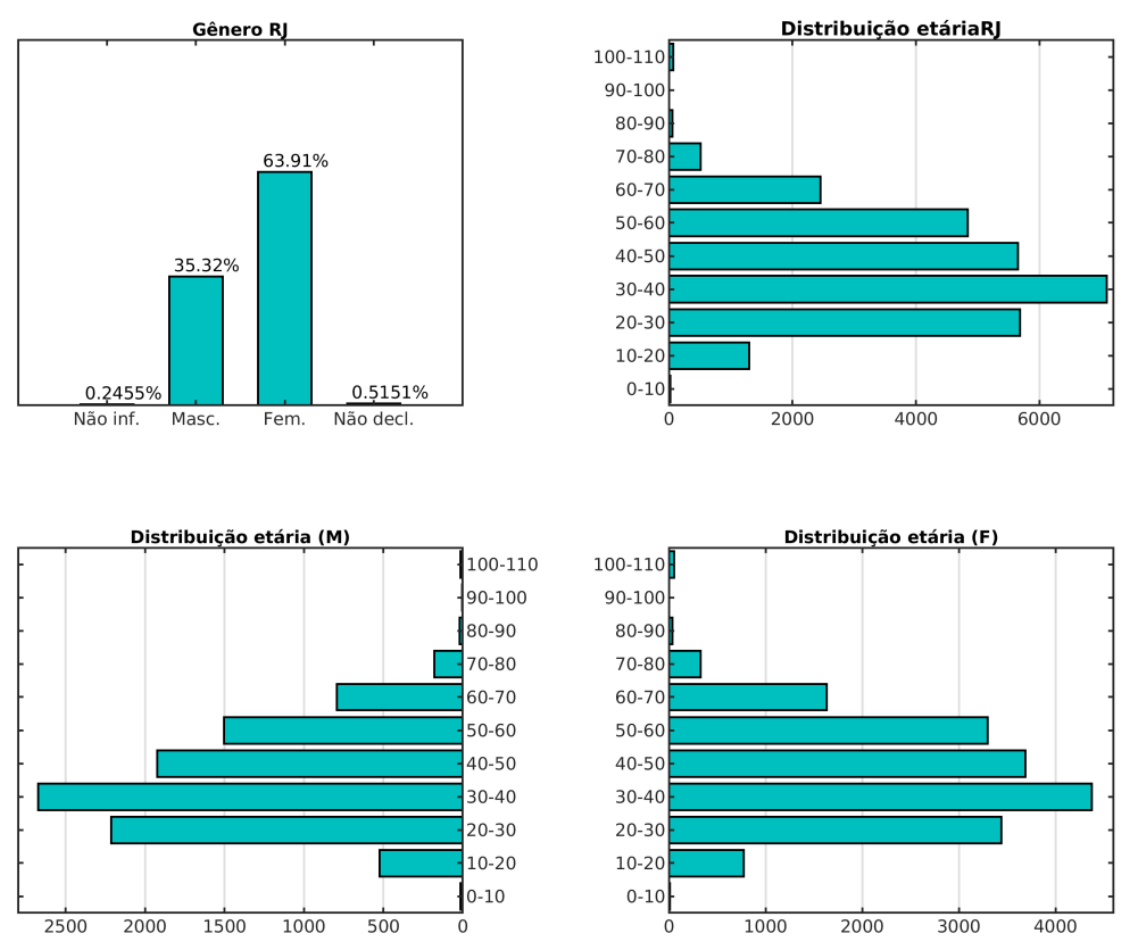

Figura 5 - Respondentes do ERJ

(gênero e faixa etária)
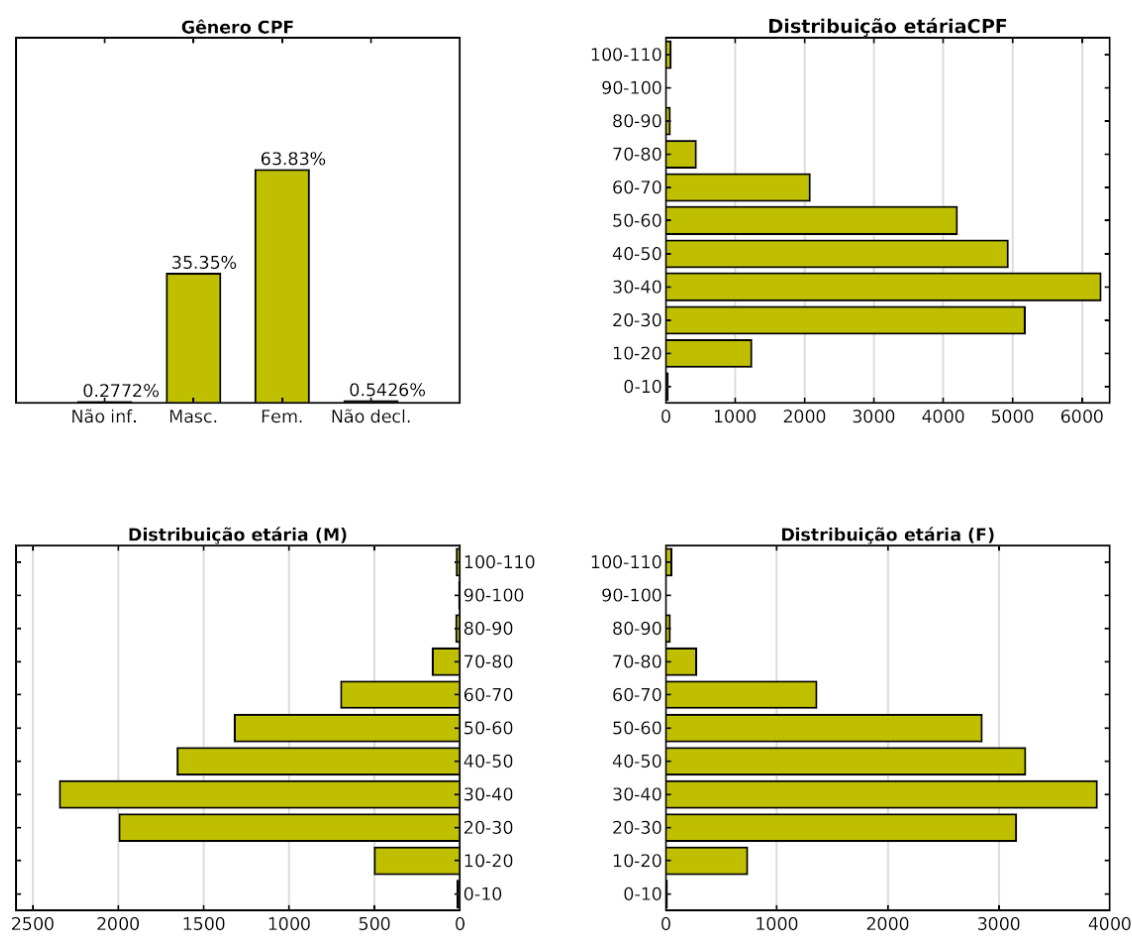

Figura 6 - Respondentes com CPF válido

(gênero e faixa etária) 

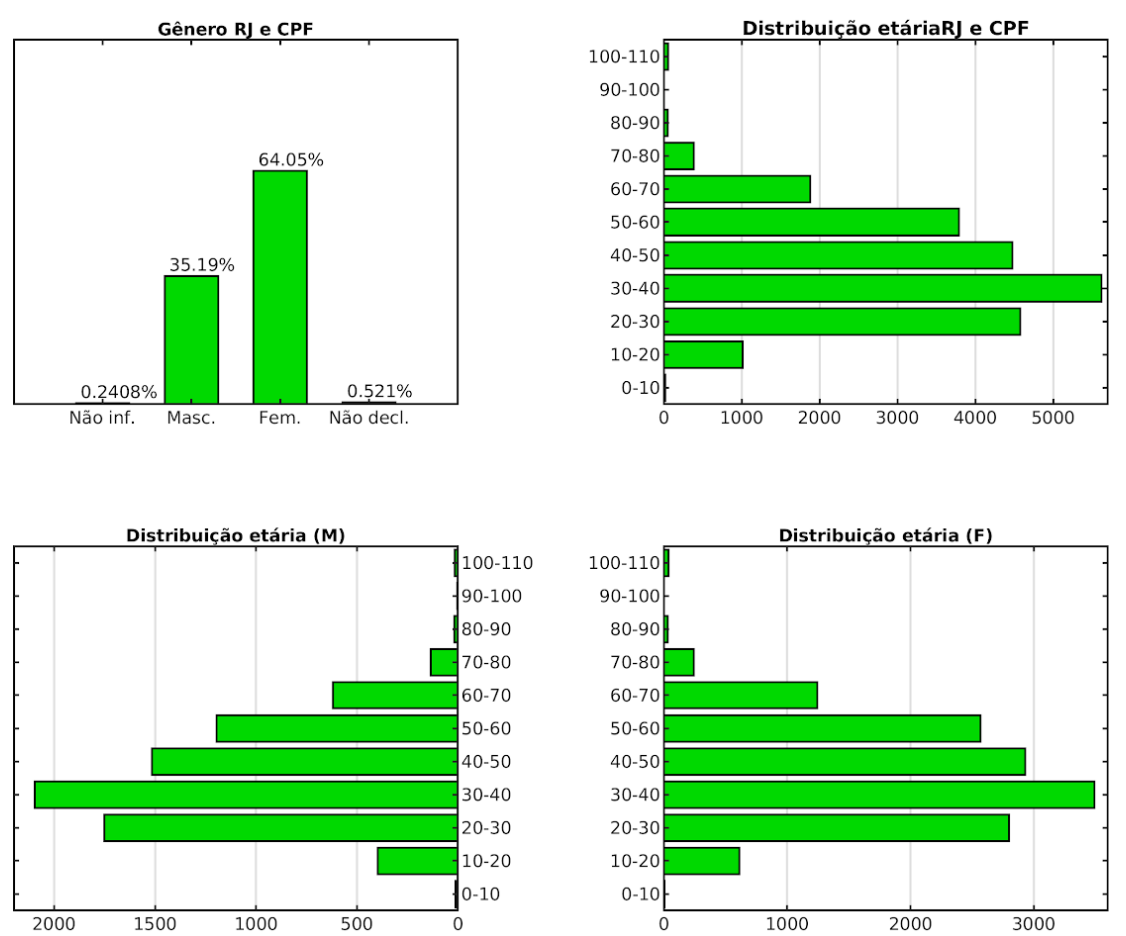

Figura 7 - Respondentes do ERJ com CPF Válido (gênero e faixa etária)
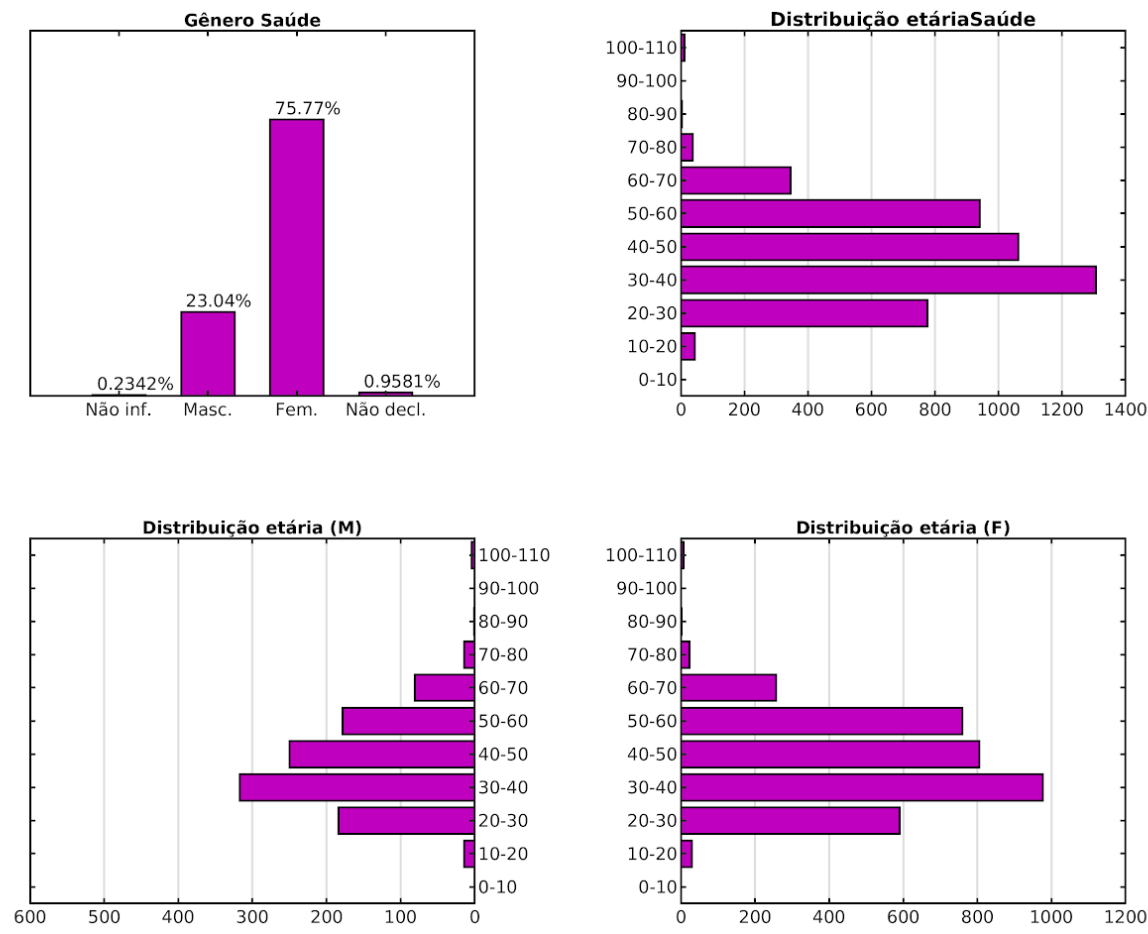

Figura 8 - Profissionais da Saúde

(gênero e faixa etária) 

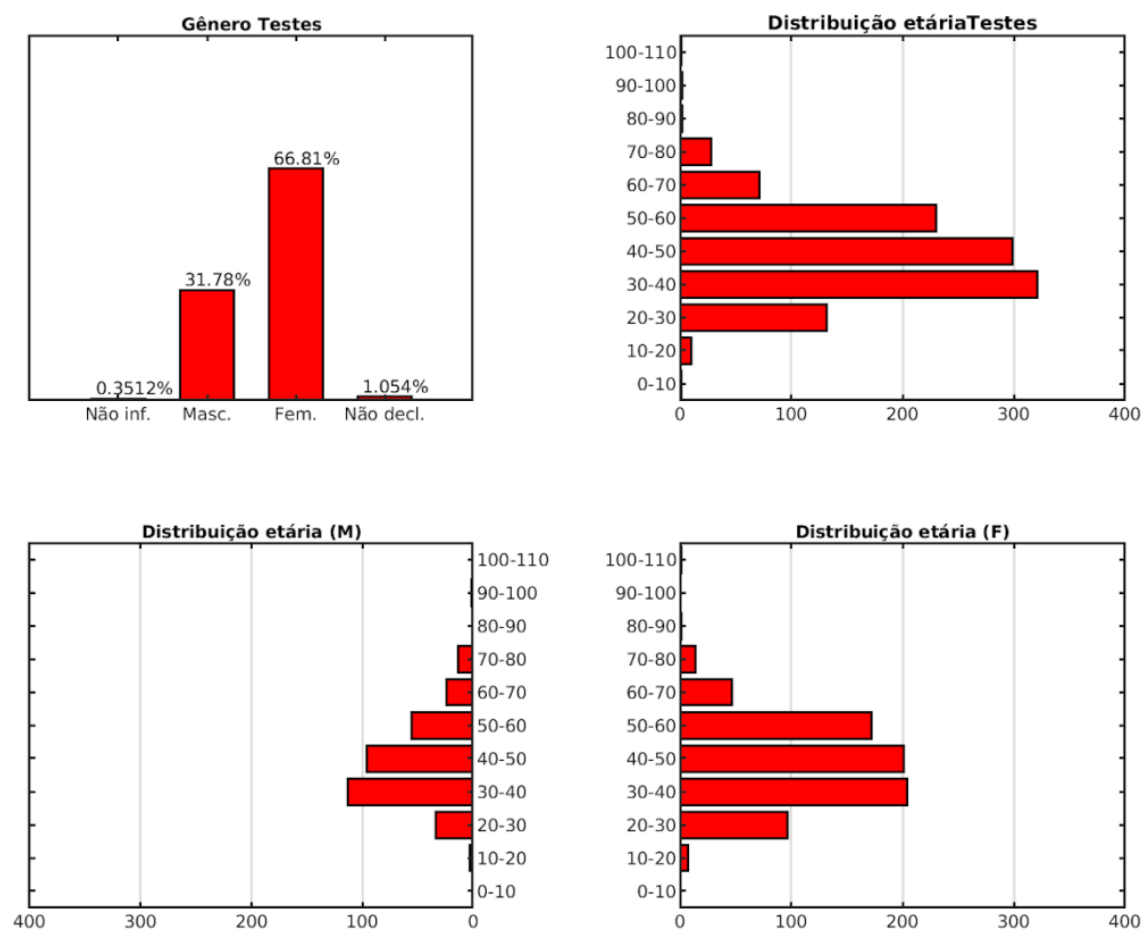

Figura 9 - Respondentes Testados

(gênero e faixa etária)

As Figuras de 10 a 15 destacam as proporções dos tipos de atendimento médico procurados pelos respondentes separadas por: todos os respondentes, respondentes do estado do Rio de Janeiro, respondentes com CPF válido, respondentes do estado do Rio de Janeiro e com CPF válido, respondentes que declararam ser profissionais da área de saúde e respondentes que declaram terem sido testados.
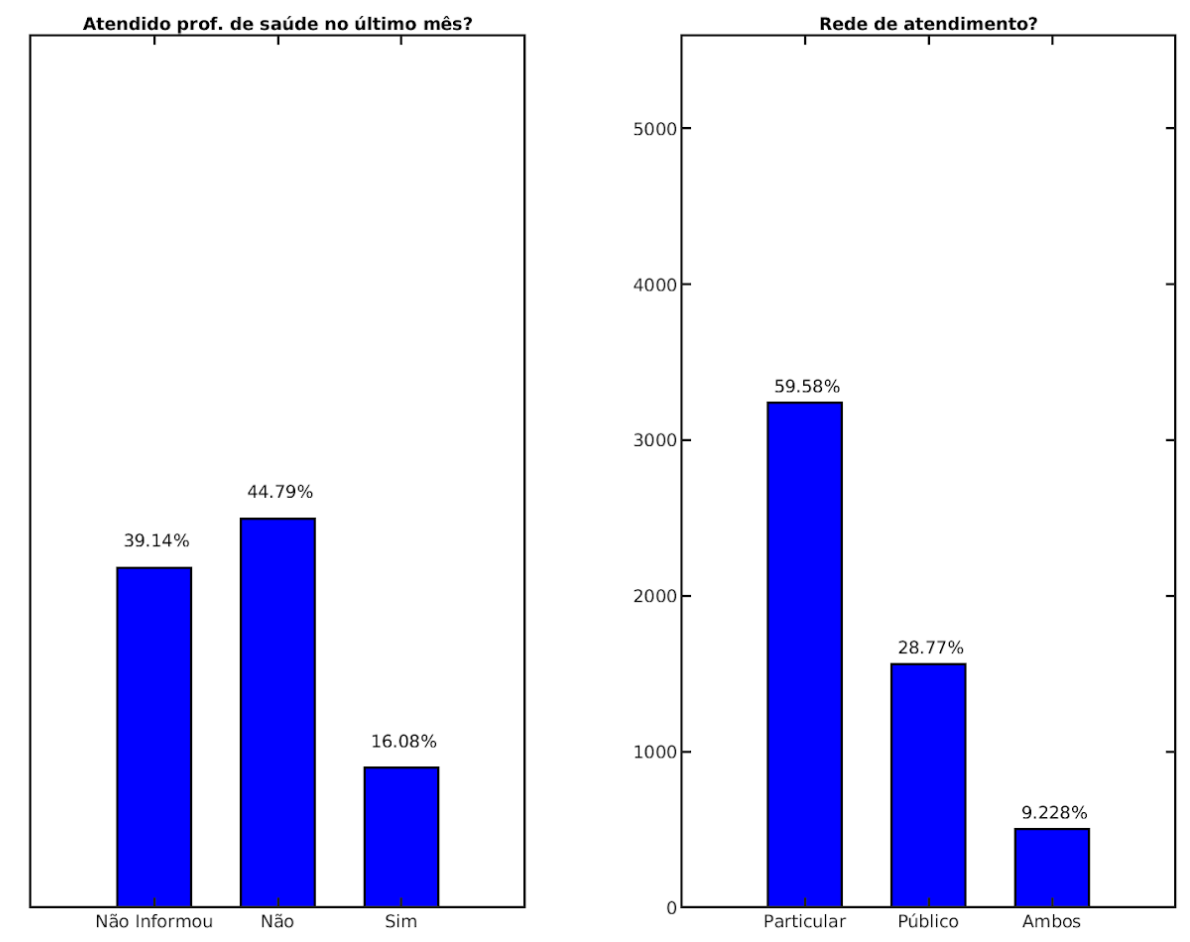

Figura 10 - Todos os Respondentes

(procuraram atendimento médico e qual tipo) 

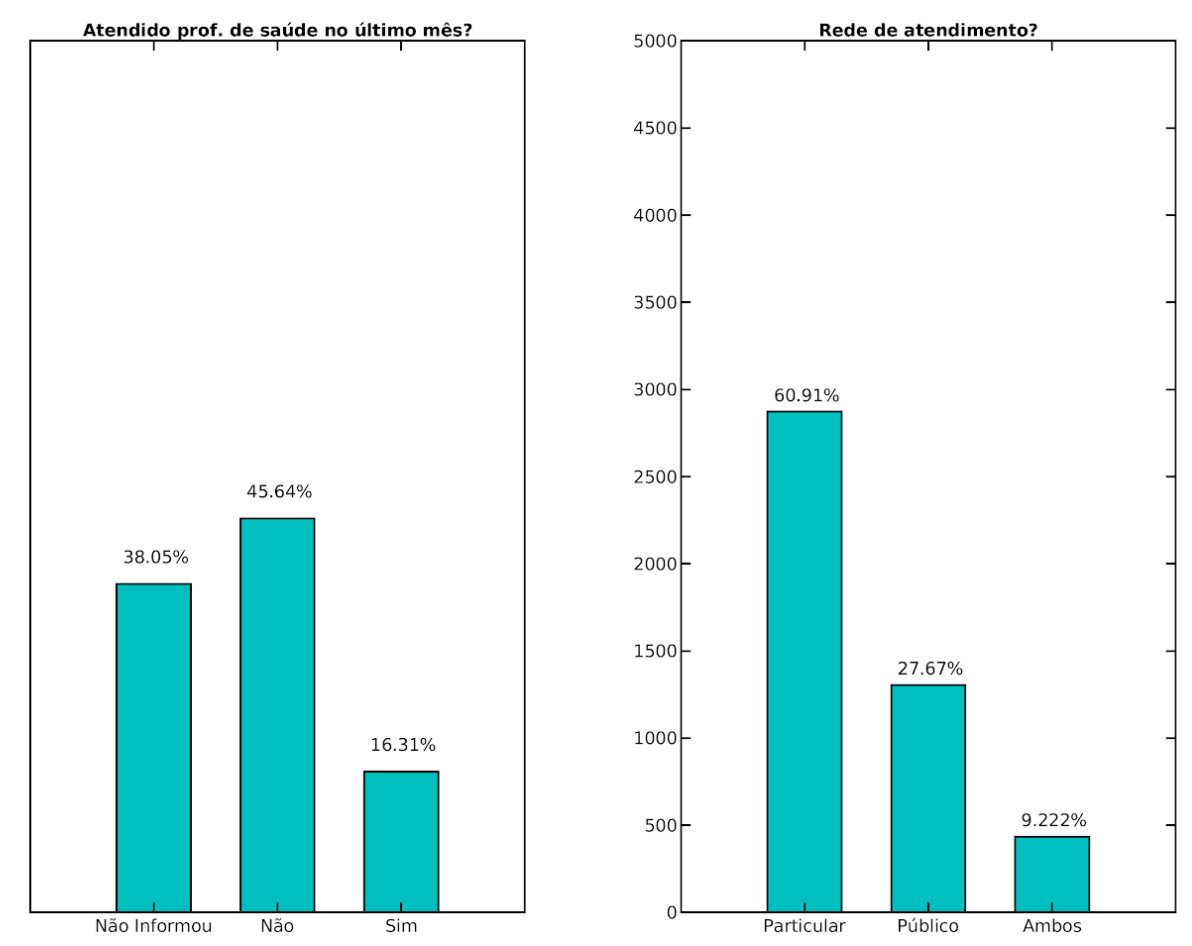

Figura 11 - Respondentes do RJ

(procuraram atendimento médico e qual tipo)
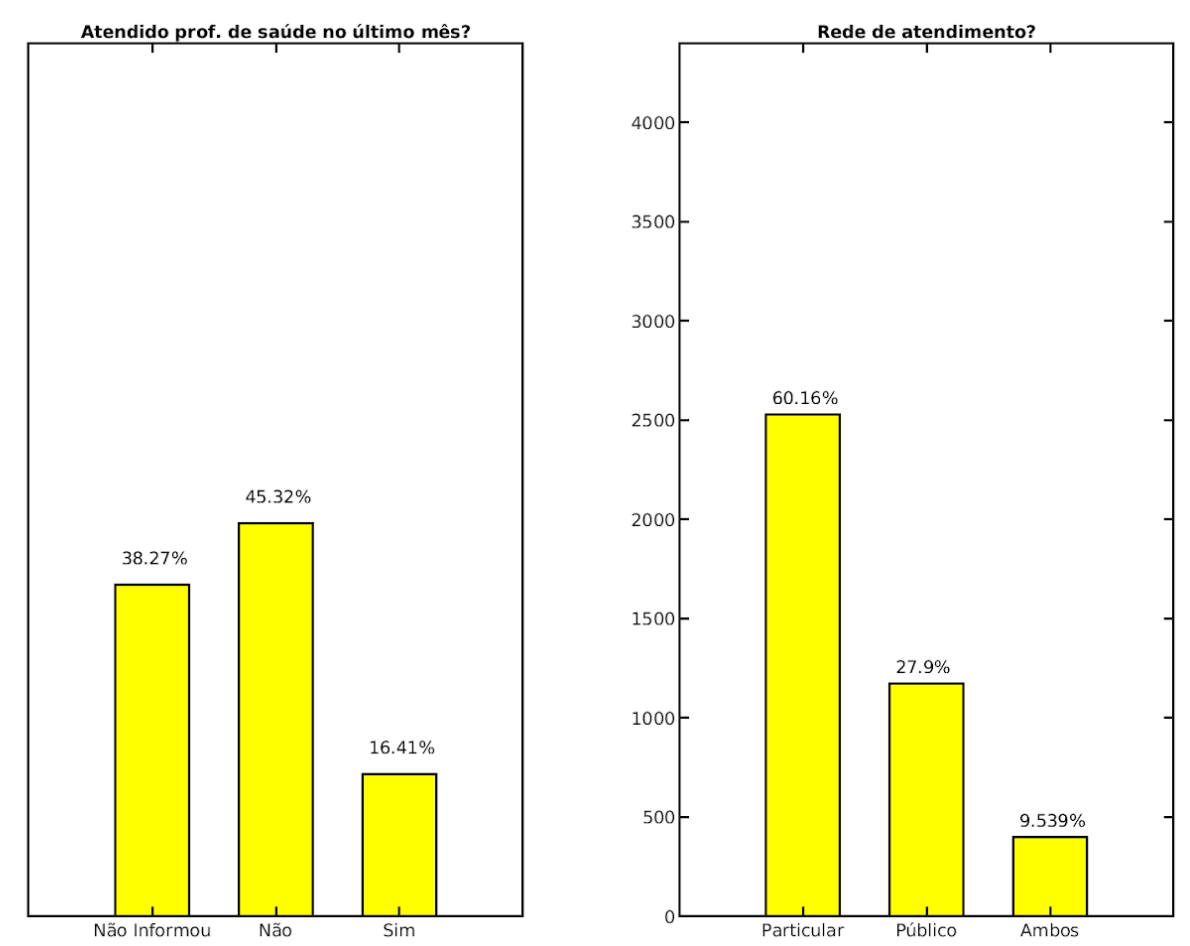

Figura 12 - Respondentes com CPF válido (procuraram atendimento médico e qual tipo) 

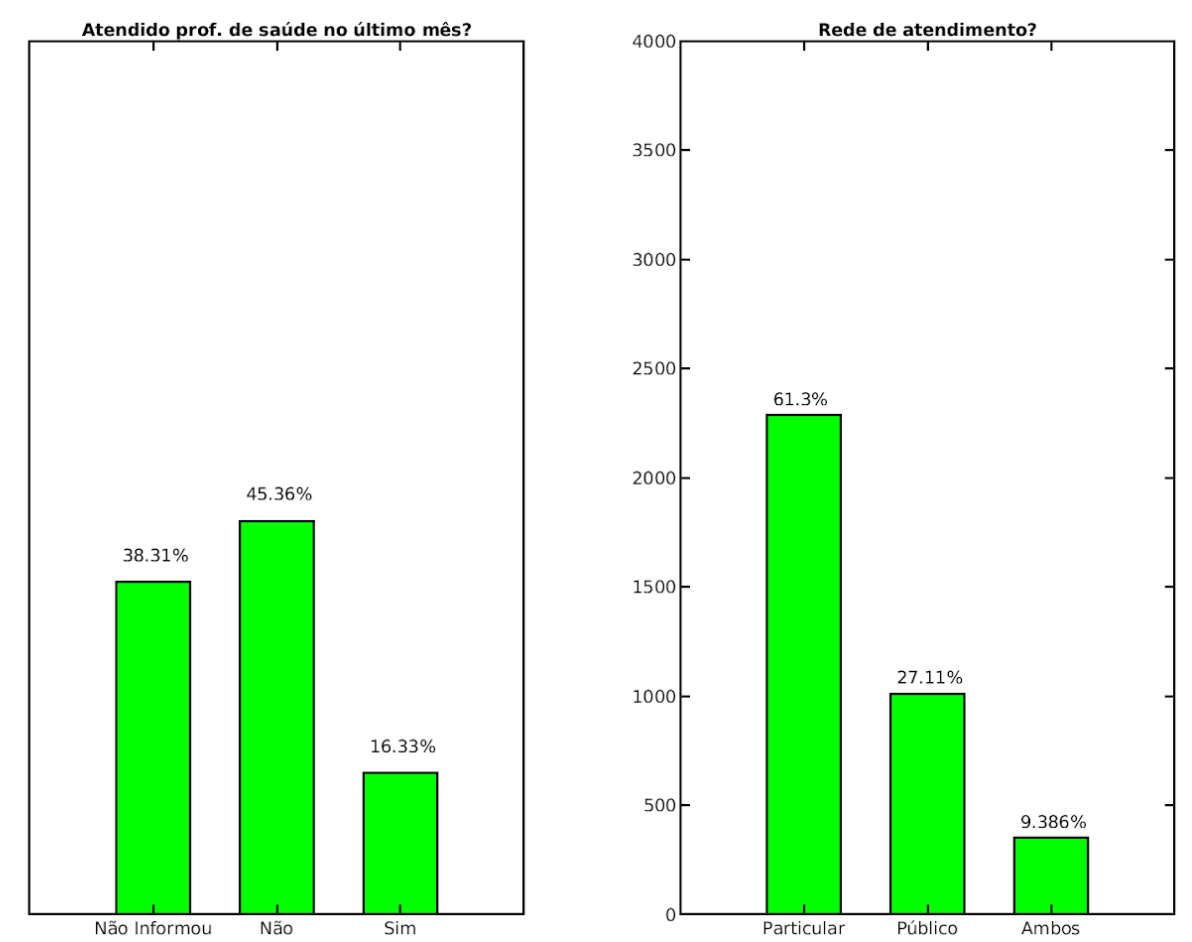

Figura 13 - Respondentes do RJ com CPF Válido

(procuraram atendimento médico e qual tipo)
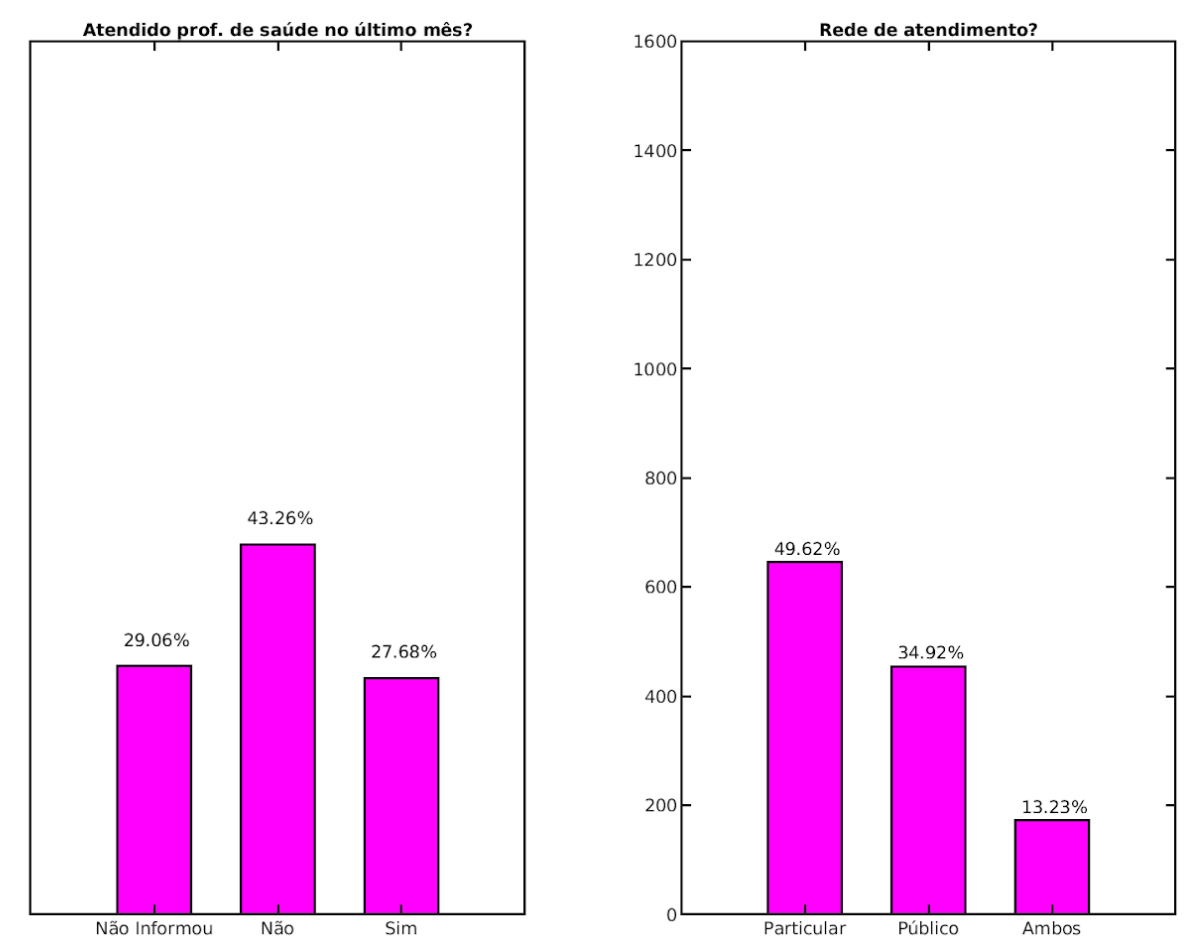

Figura 14 - Profissionais da Saúde

(procuraram atendimento médico e qual tipo) 

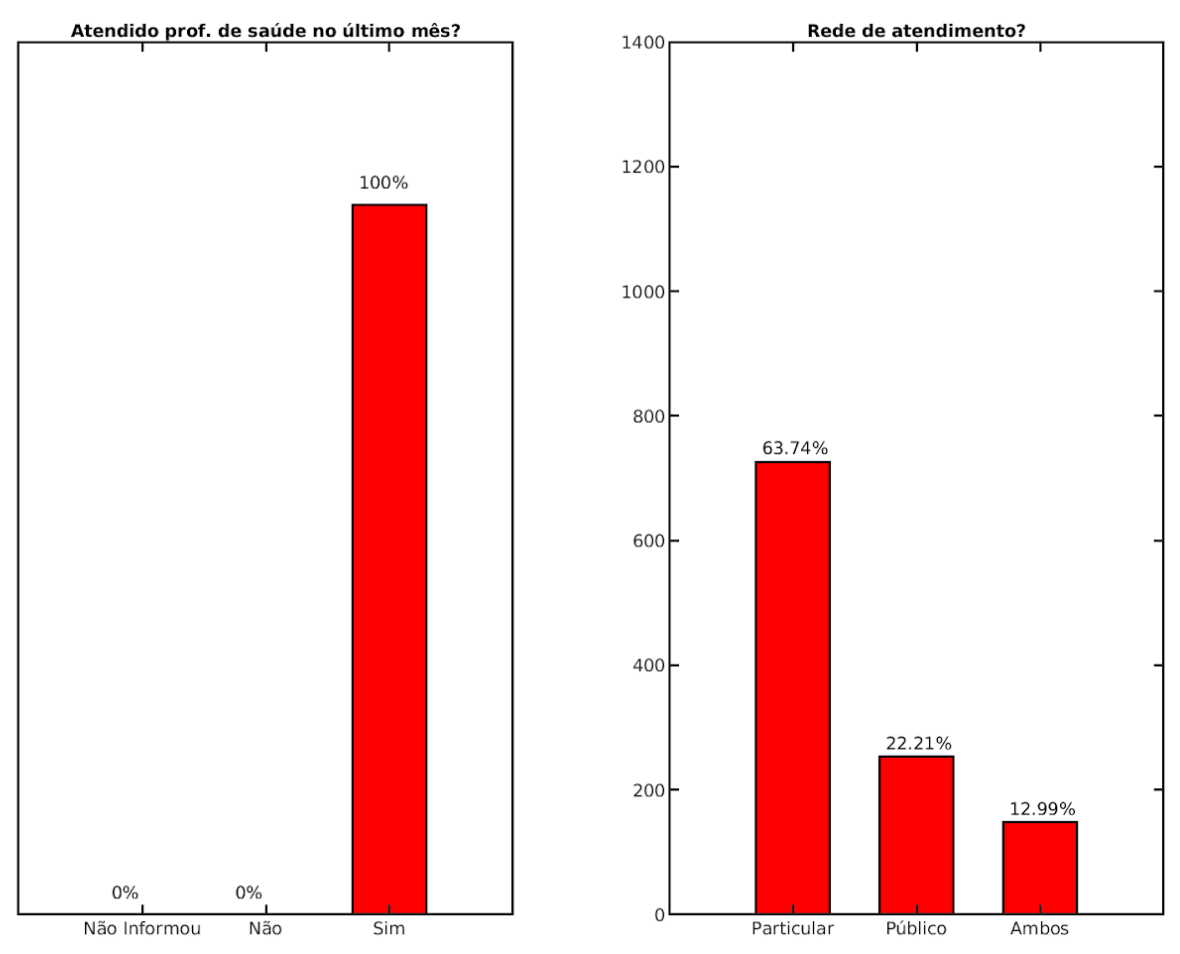

Figura 15 - Respondentes Testados

(procuraram atendimento médico e qual tipo)

As Figuras de 16 a 21 apresentam as proporções dos respondentes que indicaram apresentar algum sintoma e as datas de ocorrência dos mesmos declaradas pelos respondentes separadas por: todos os respondentes (Figura 16), respondentes do estado do Rio de Janeiro (Figura 17), respondentes com CPF válido (Figura 18), respondentes do estado do Rio de Janeiro e com CPF válido (Figura 19), respondentes que declararam ser profissionais da área de saúde (Figura 20) e respondentes que declaram terem sido testados (Figura 21).
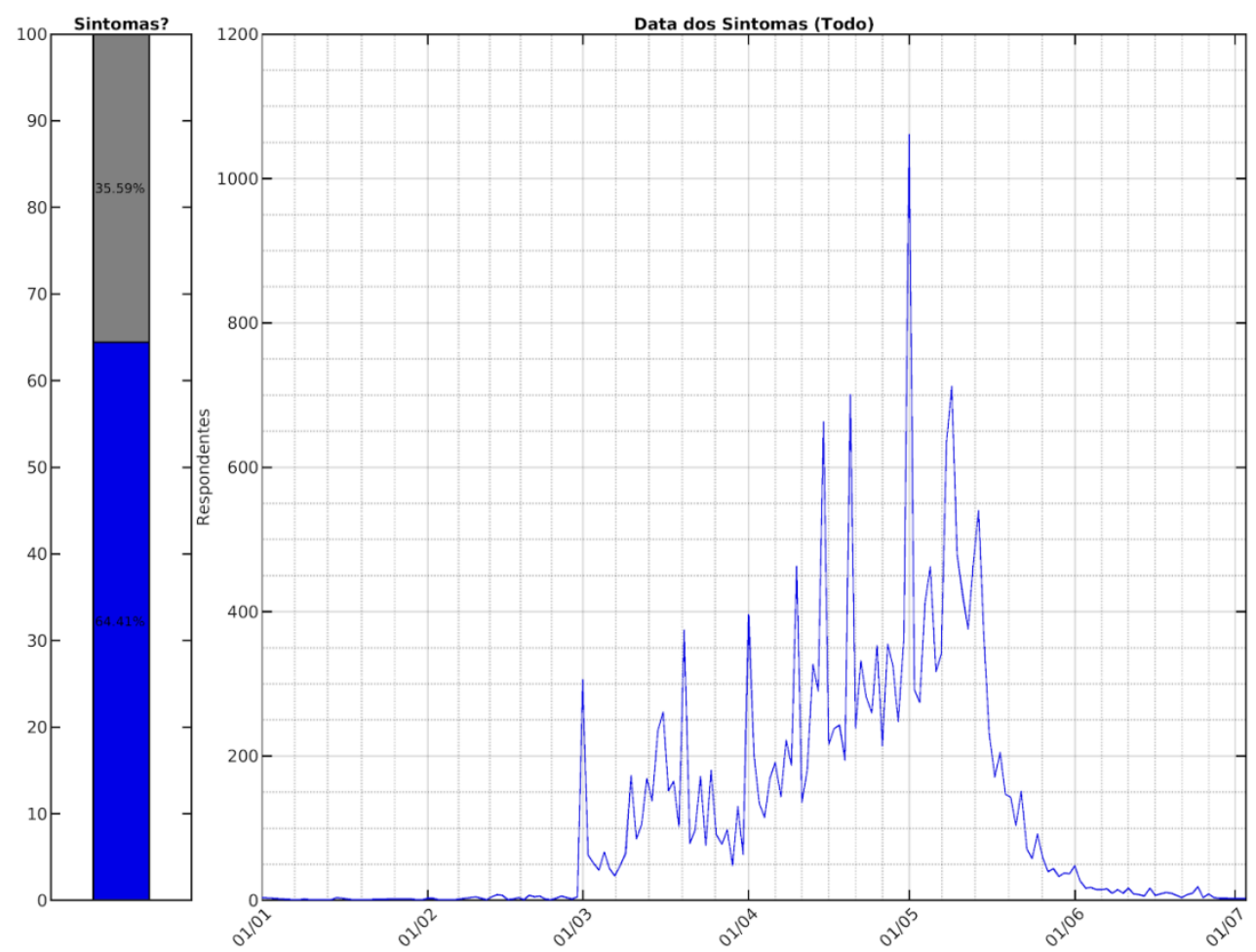

Figura 16 - Todos os Respondentes (apresentaram algum sintoma e data de ocorrência) 

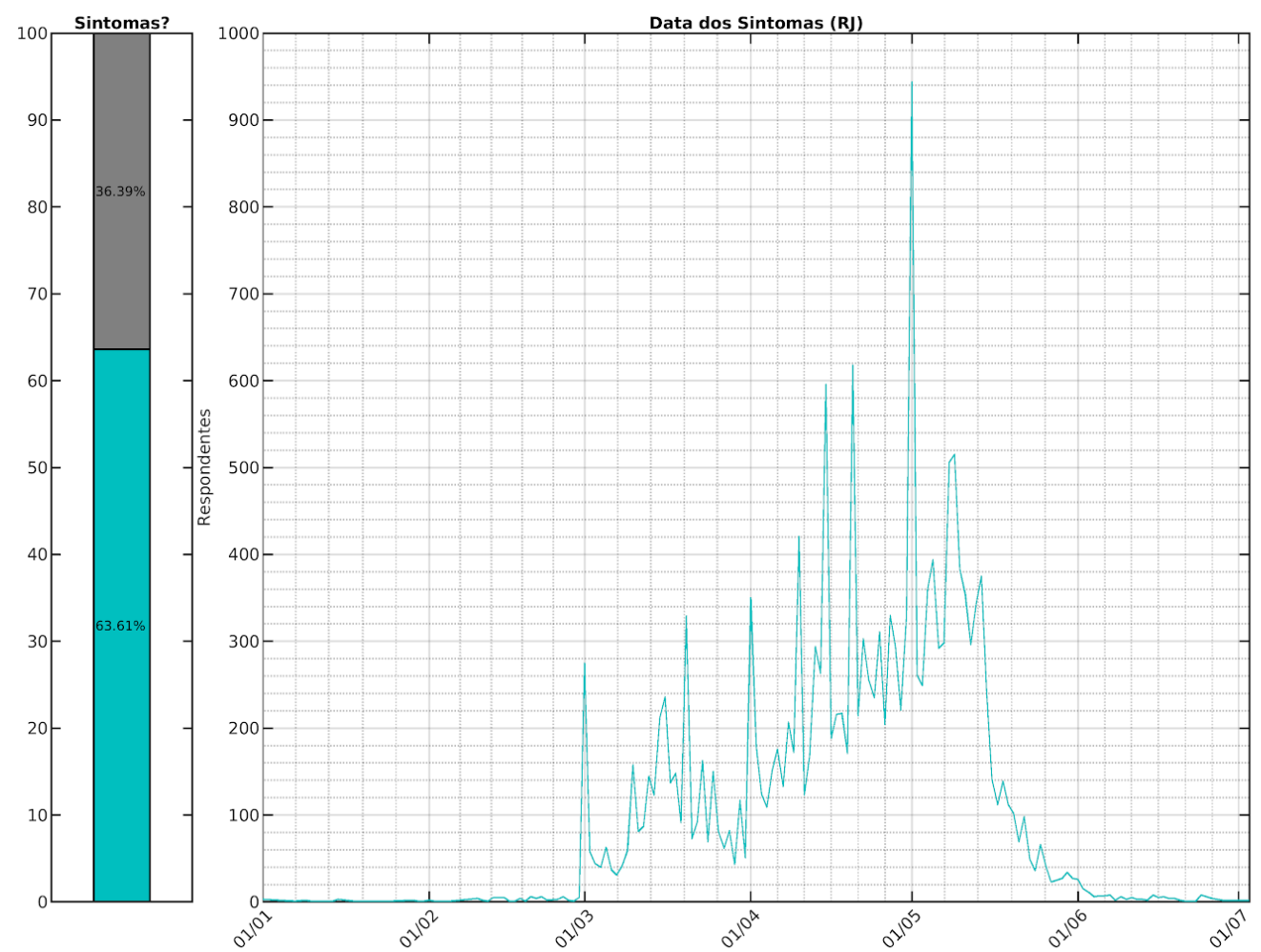

Figura 17 - Respondentes do RJ (apresentaram algum sintoma e data de ocorrência)
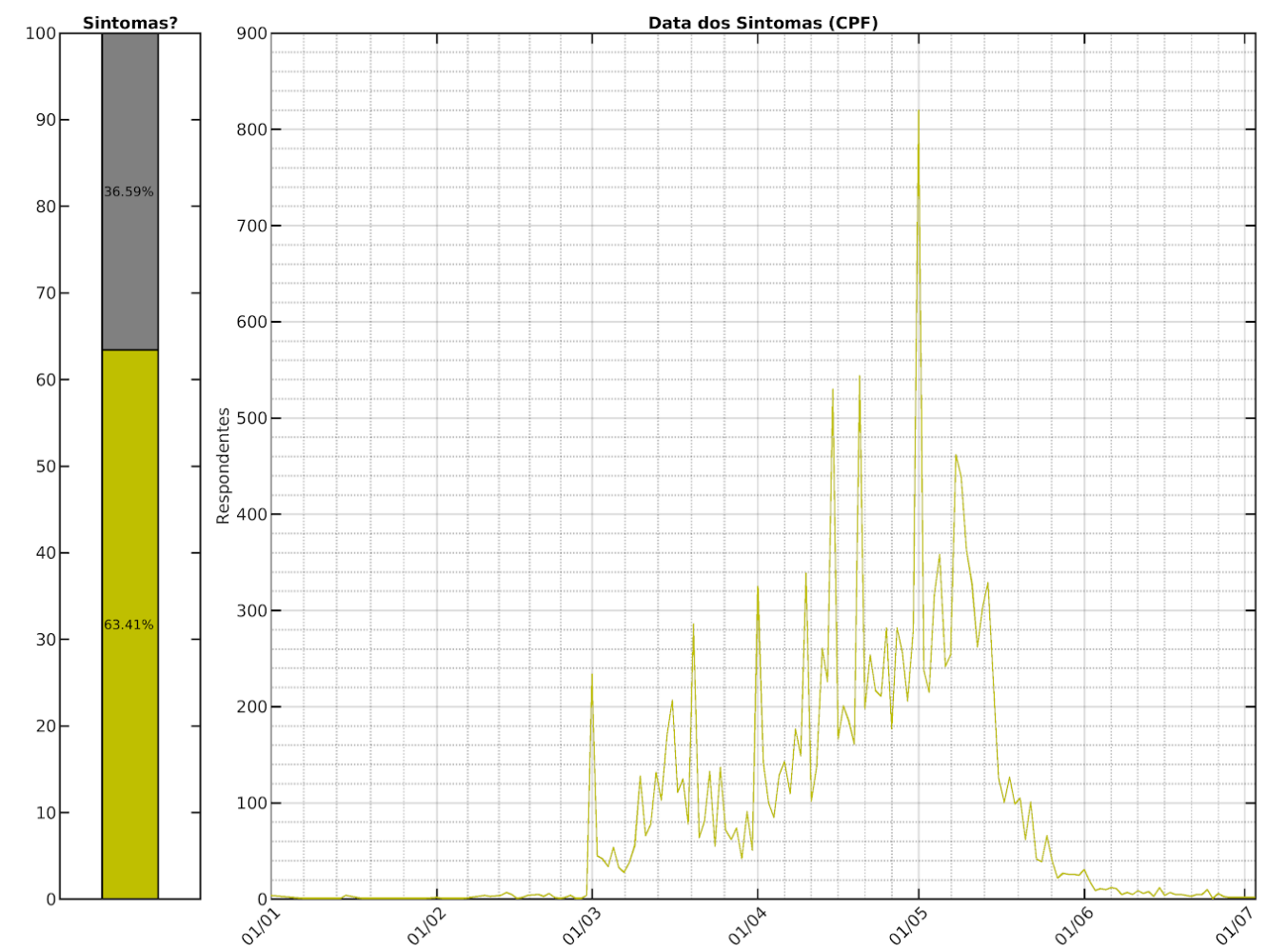

Figura 18 - Respondentes com CPF válido (apresentaram algum sintoma e data de ocorrência) 

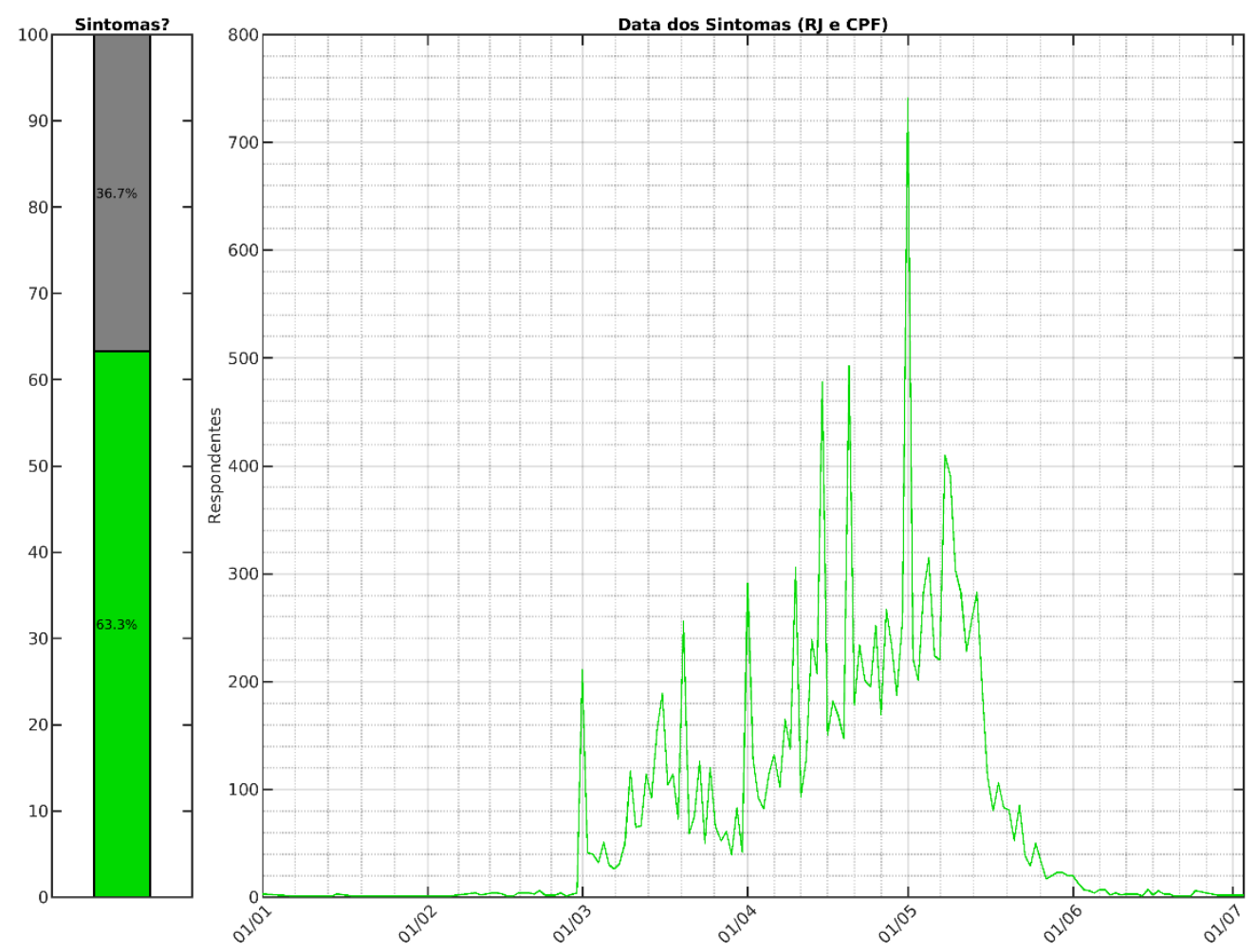

Figura 19 - Respondentes do RJ com CPF Válido (apresentaram algum sintoma e data de ocorrência)
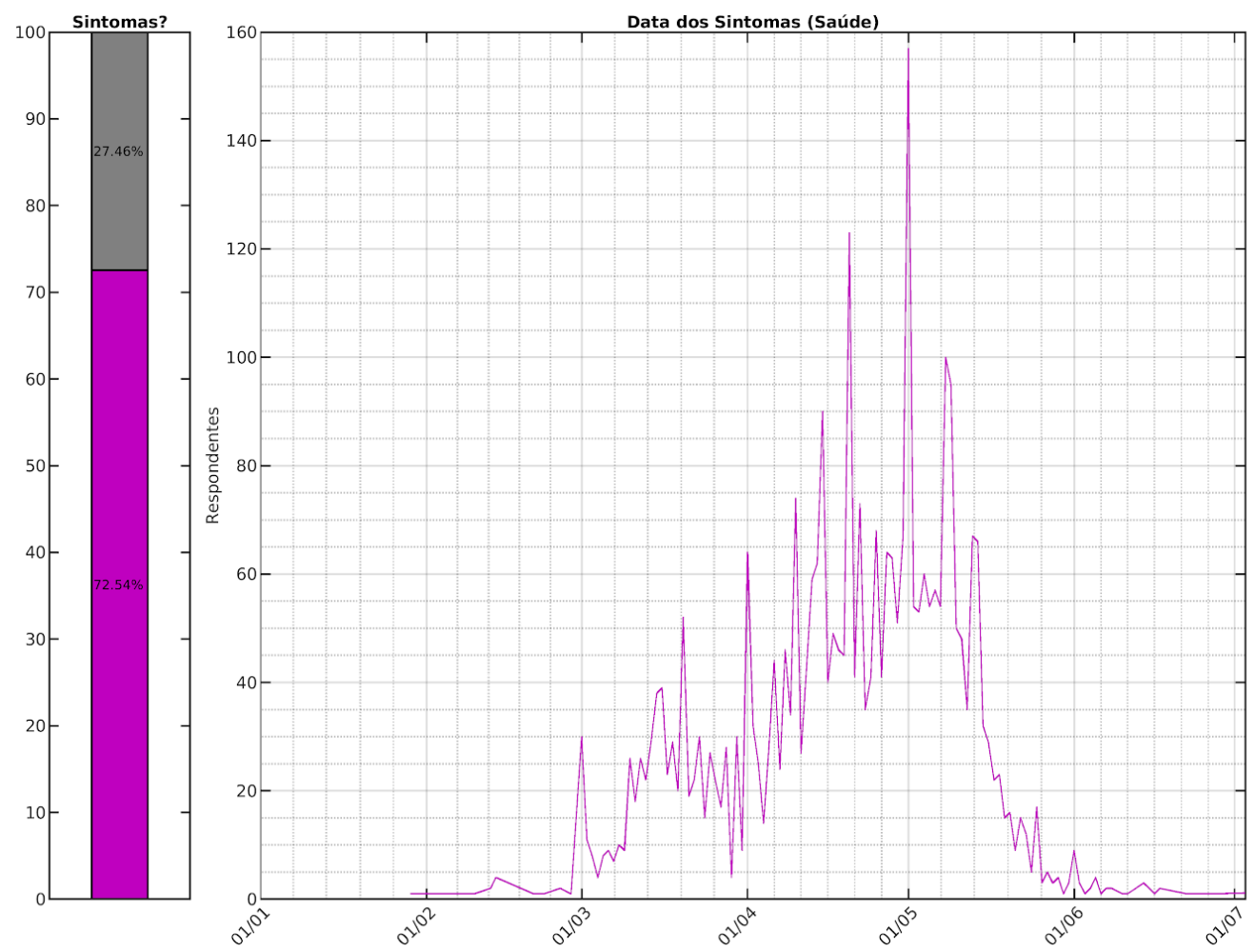

Figura 20 - Profissionais da Saúde

(apresentaram algum sintoma e data de ocorrência) 

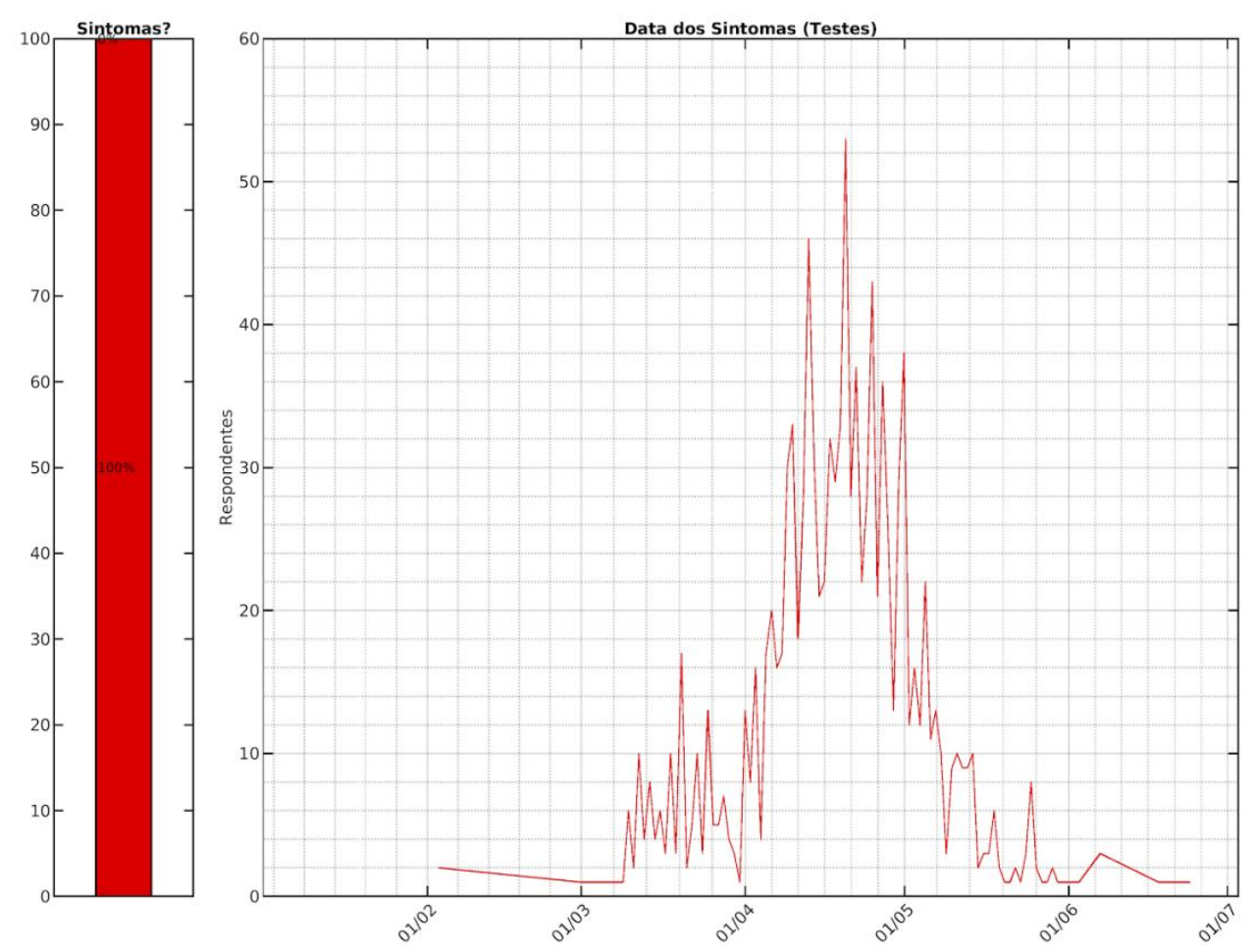

Figura 21 - Respondentes Testados

(apresentaram algum sintoma e data de ocorrência)

As Figuras de 22 a 27 descrevem as proporções dos sintomas relatados pelos respondentes separadas por: todos os respondentes (Figura 22), respondentes do estado do Rio de Janeiro (Figura 23), respondentes com CPF válido(Figura 24), respondentes do estado do Rio de Janeiro e com CPF válido (Figura 25), respondentes que declararam ser profissionais da área de saúde (Figura 26) e respondentes que declaram terem sido testados(Figura 27).
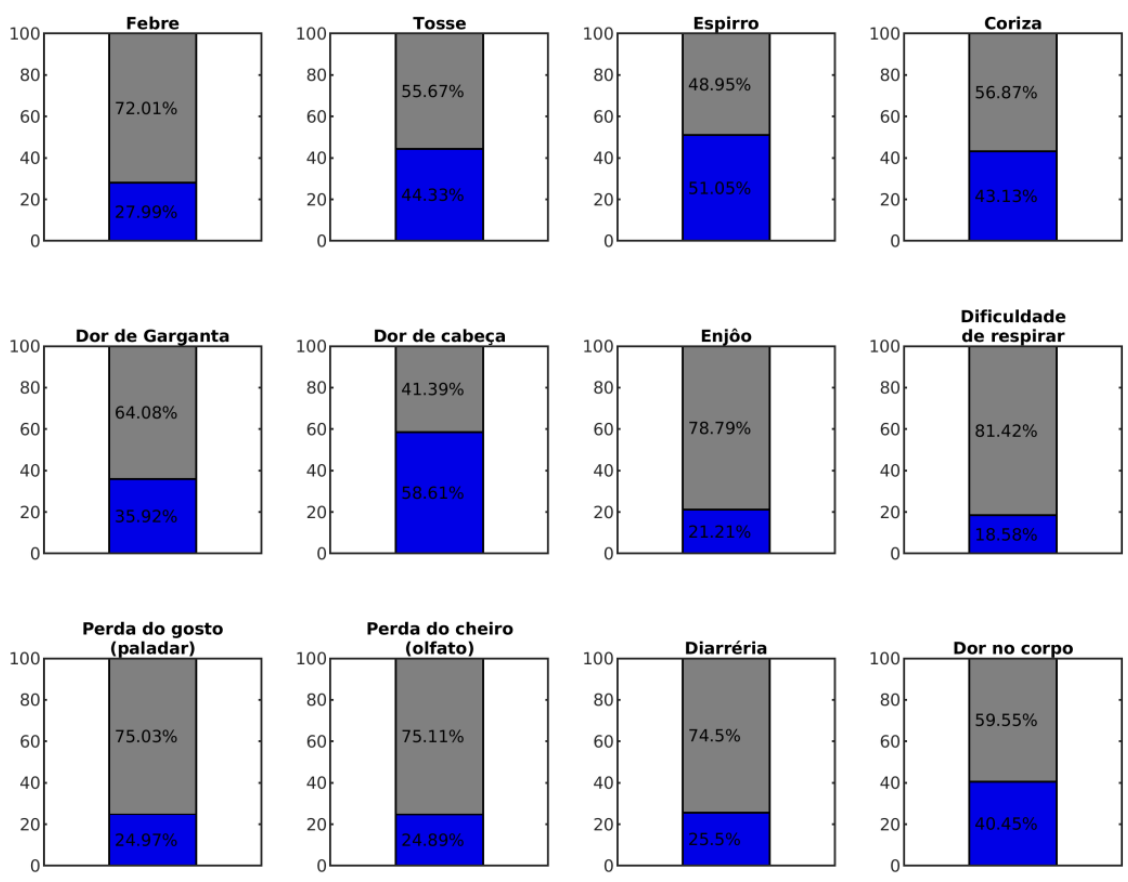

Figura 22 - Todos os Respondentes (sintomas relatados) 

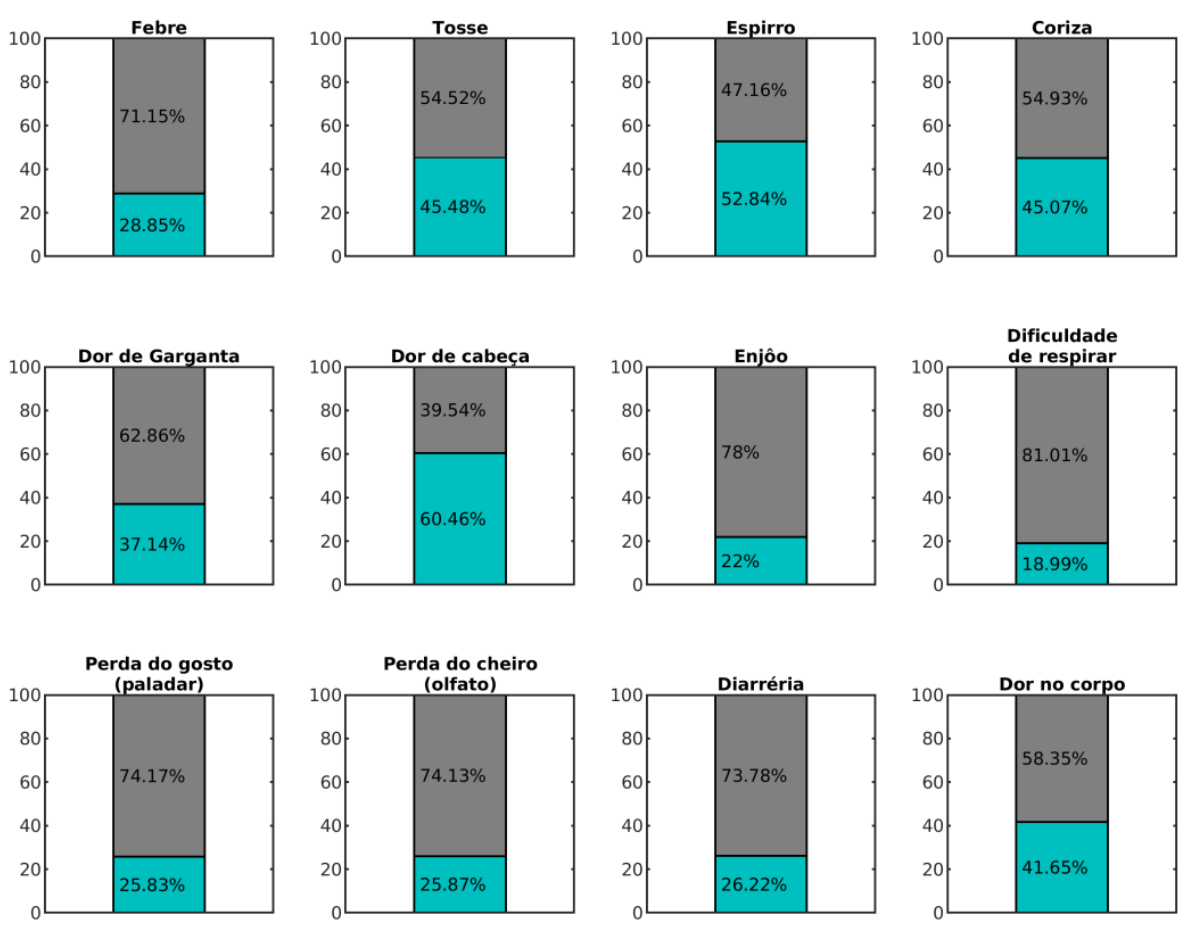

Figura 23 - Respondentes do RJ

(sintomas relatados)
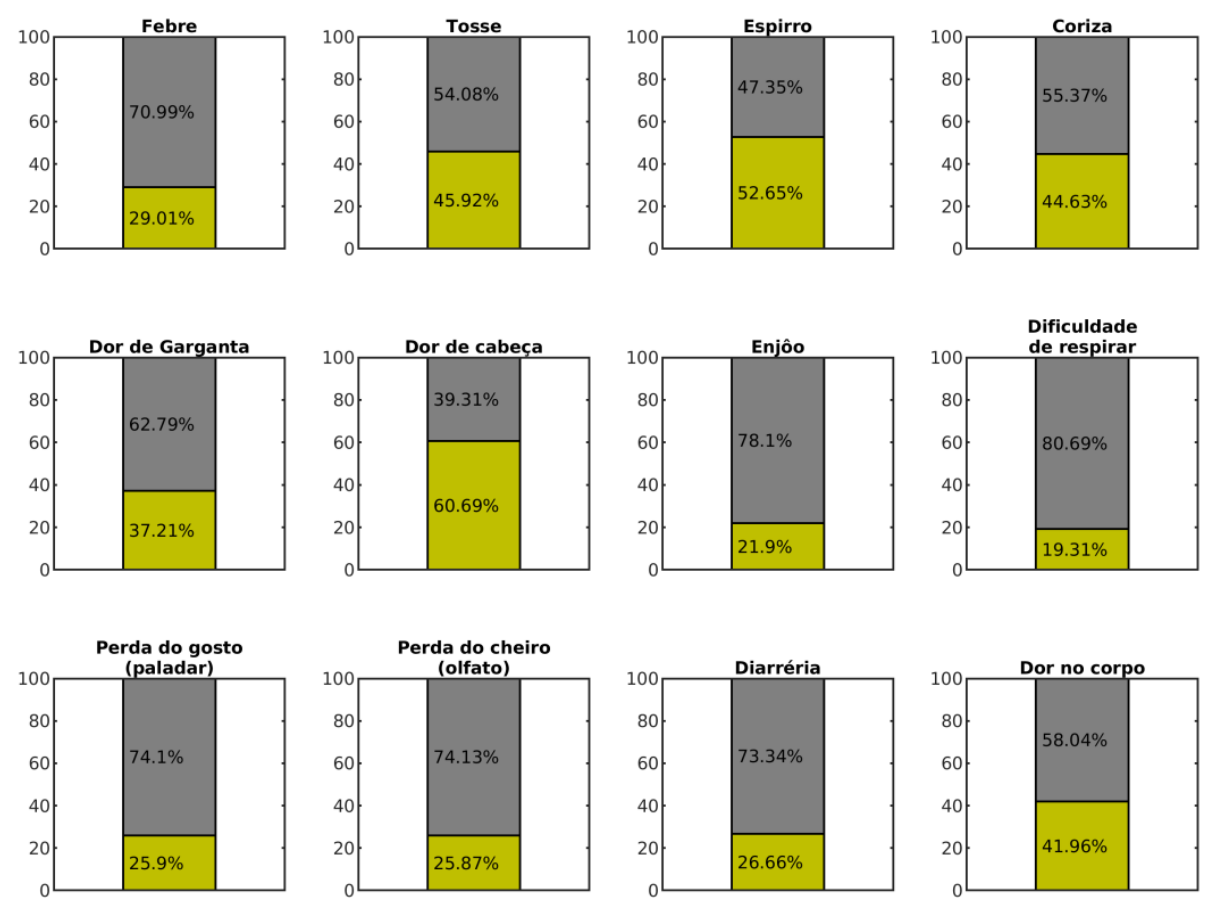

Figura 24 - Respondentes com CPF válido (sintomas relatados) 

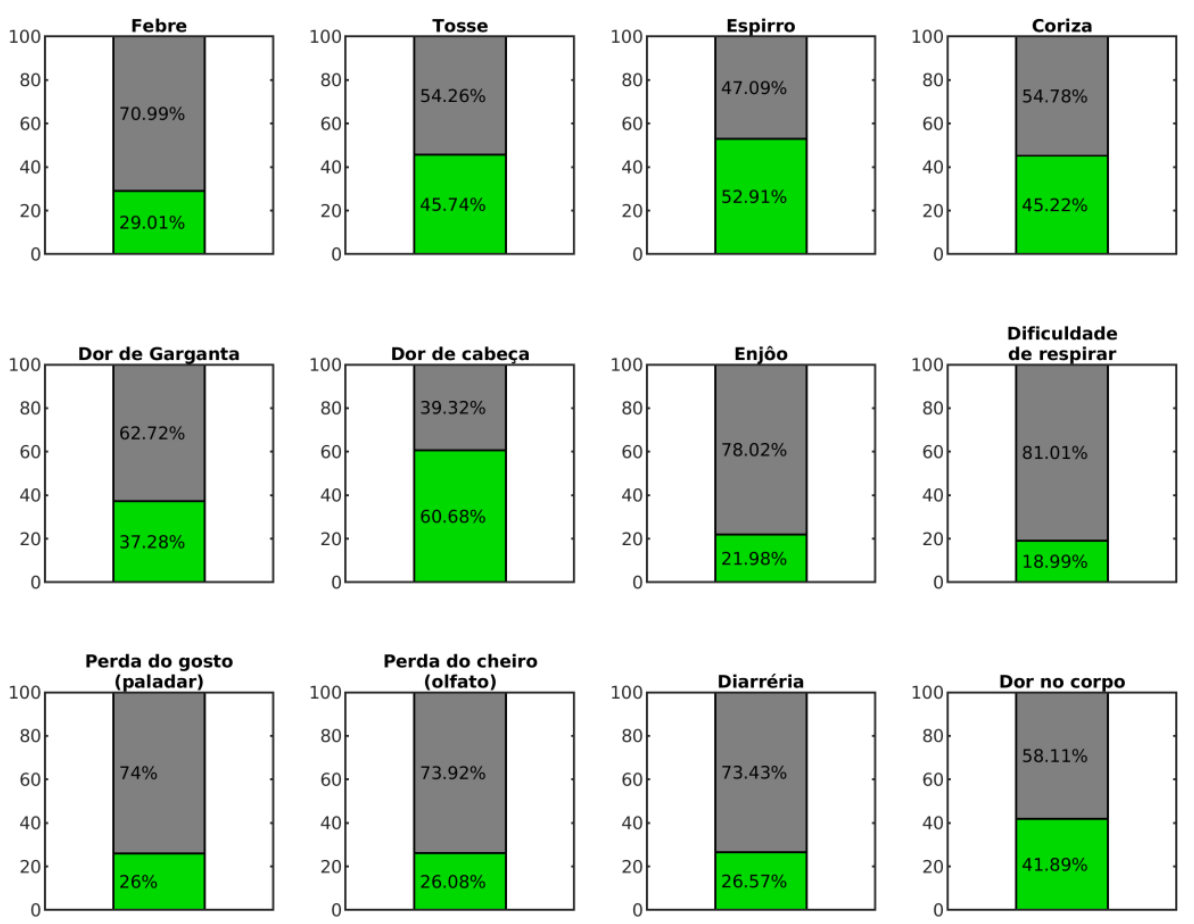

Figura 25 - Respondentes do RJ com CPF Válido (sintomas relatados)
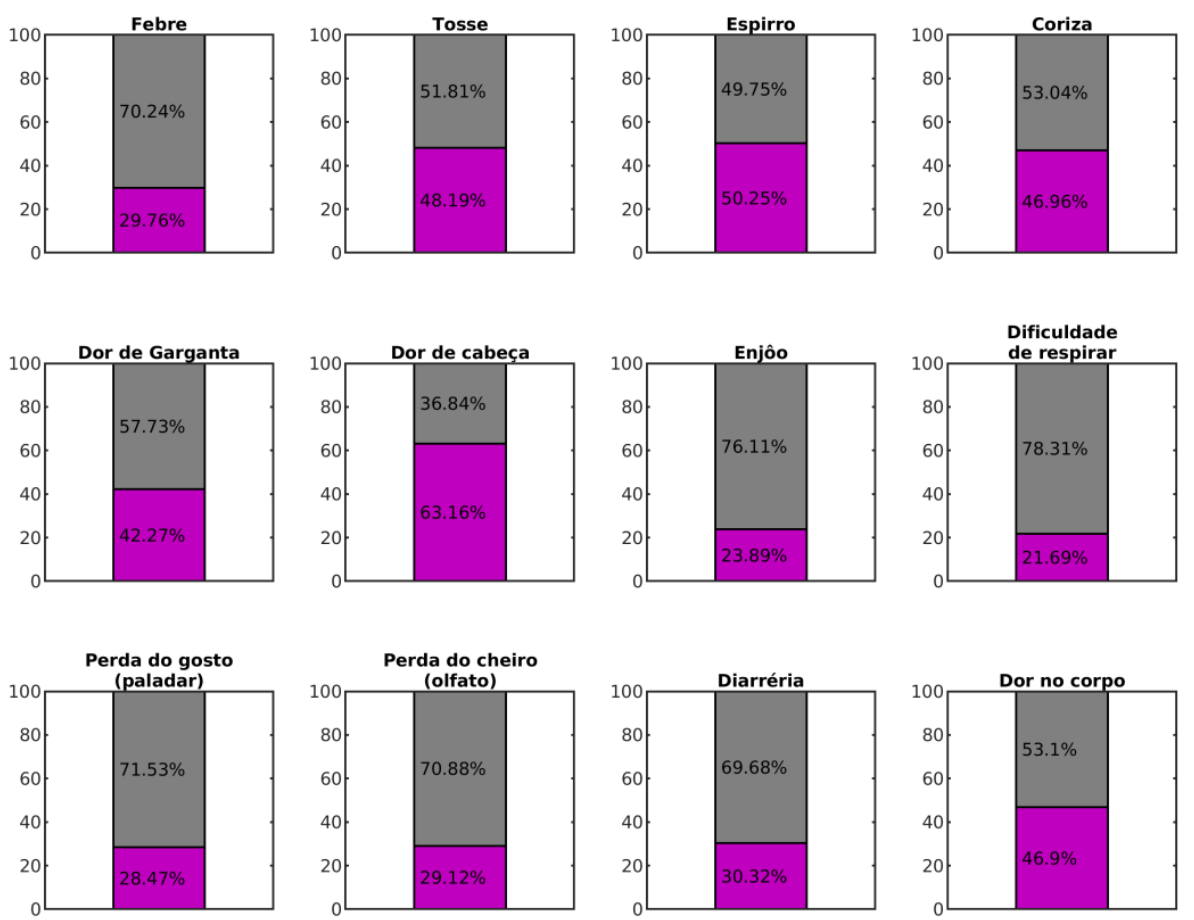

Figura 26 - Profissionais da Saúde

(sintomas relatados) 

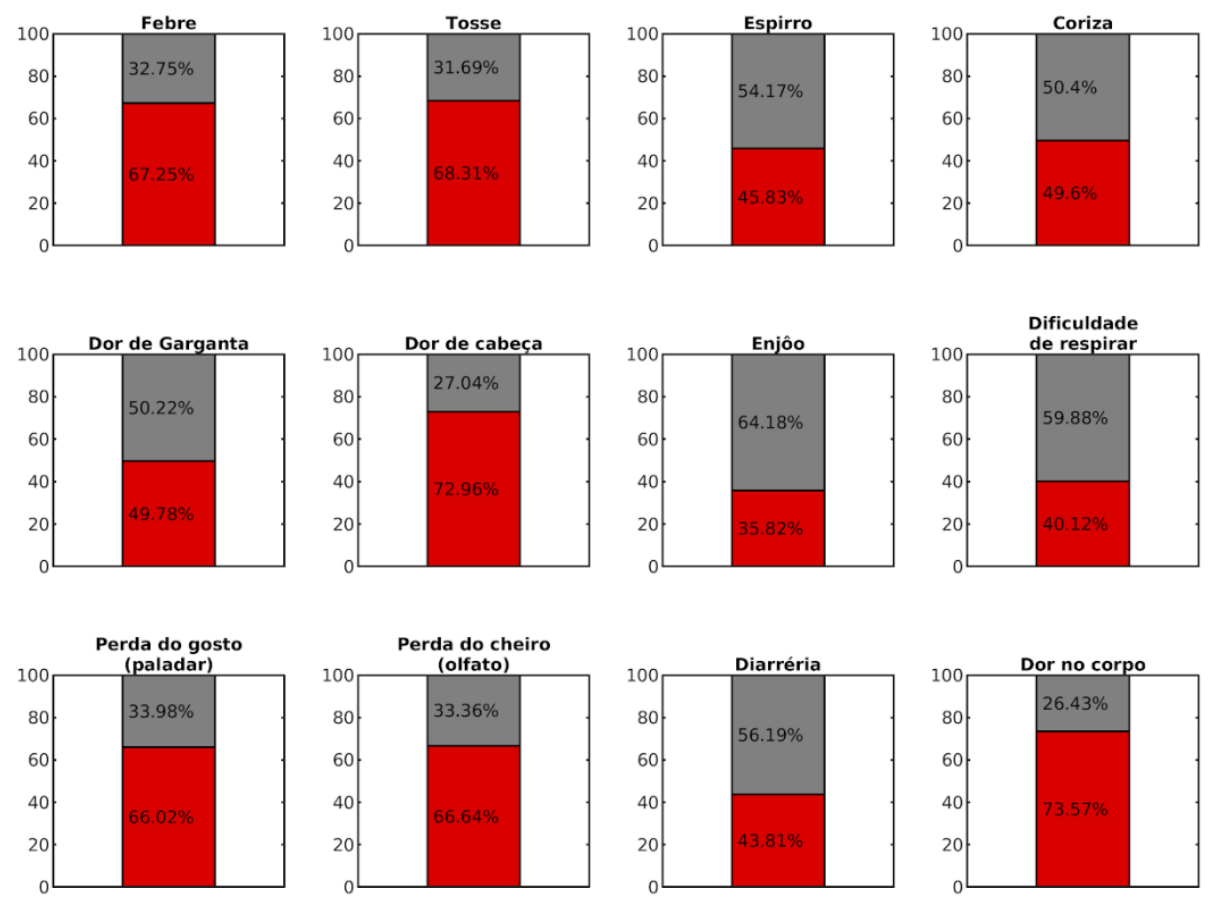

Figura 27 - Respondentes Testados (sintomas relatados)

As proporções das percepções dos respondentes sobre a relação da COVID-19 em amigos e parentes podem ser observadas nas Figuras 28 a 33, separadas por: todos os respondentes (Figura 28), respondentes do estado do Rio de Janeiro (Figura 29), respondentes com CPF válido (Figura 30), respondentes do estado do Rio de Janeiro e com CPF válido(Figura 31), respondentes que declararam ser profissionais da área de saúde (Figura 32) e respondentes que declaram terem sido testados (Figura 33).

Os gráficos apresentados na Figura 28 apresentam as informações relatadas por todos os respondentes com relação a se algum parente ou amigo próximo teve (ou tem): suspeita de COVID-19 (a), confirmação de COVID-19 (b) e a suspeita ou confirmação (c); e os casos de falecimento: com suspeita de morte por COVID19 (d), confirmação de morte por COVID-19 (e) e a suspeita ou confirmação de morte por COVID-19 (f).

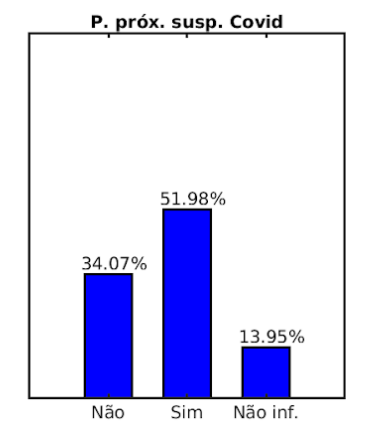

(a)

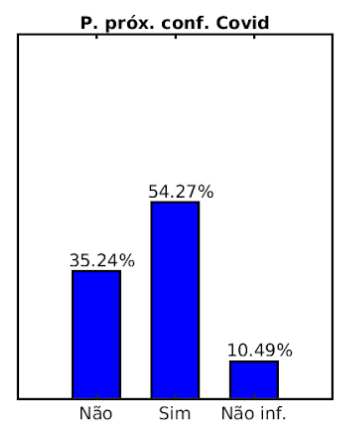

(b)

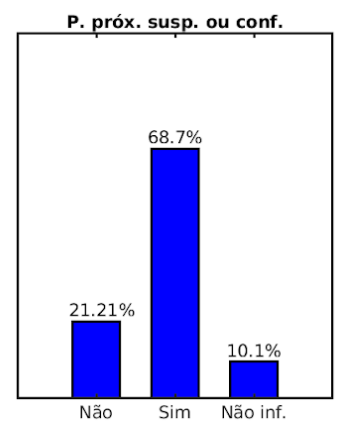

(c) 


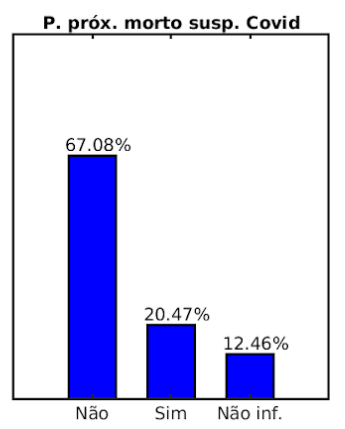

(d)

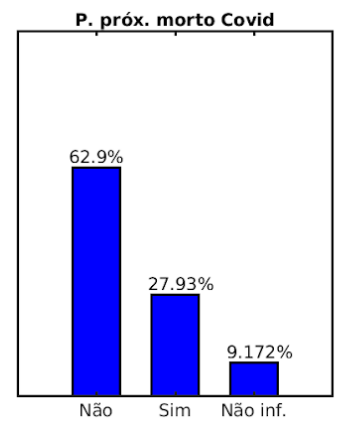

(e)

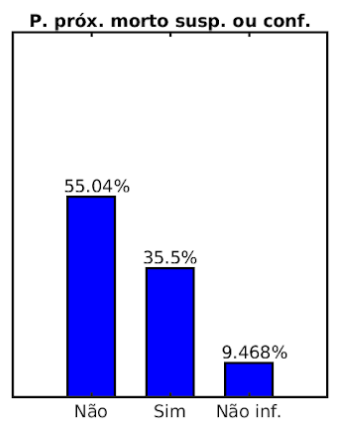

(f)

Figura 28 - Todos os Respondentes (percepções relatadas)

Os gráficos apresentados na Figura 29 apresentam as informações relatadas pelos respondentes do estado do Rio de Janeiro com relação a se algum parente ou amigo próximo teve (ou tem): suspeita de COVID-19 (a), confirmação de COVID-19 (b) e a suspeita ou confirmação (c); e os casos de falecimento: com suspeita de morte por COVID-19 (d), confirmação de morte por COVID-19 (e) e a suspeita ou confirmação de morte por COVID-19 (f).

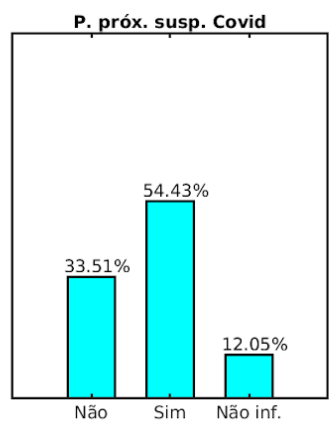

(a)

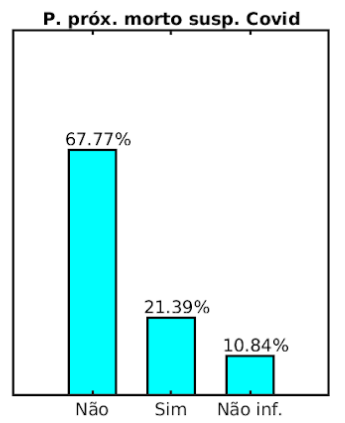

(d)

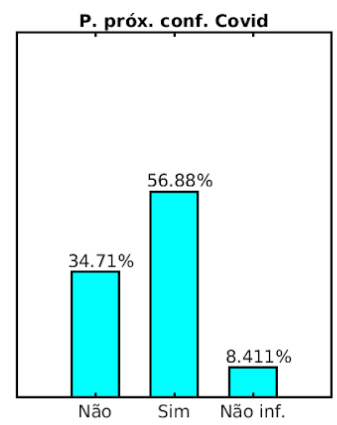

(b)

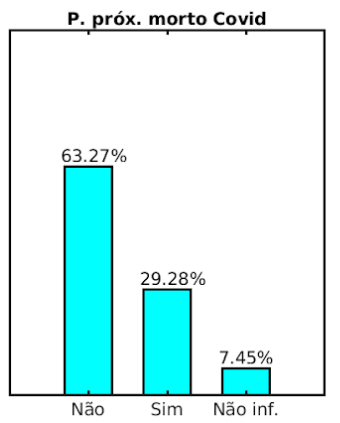

(e)

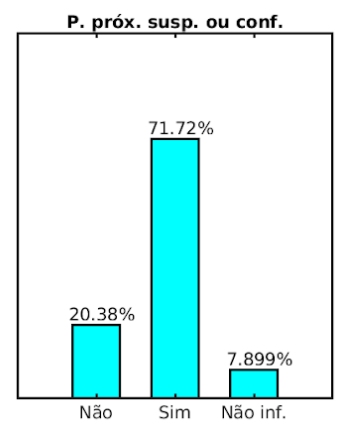

(c)

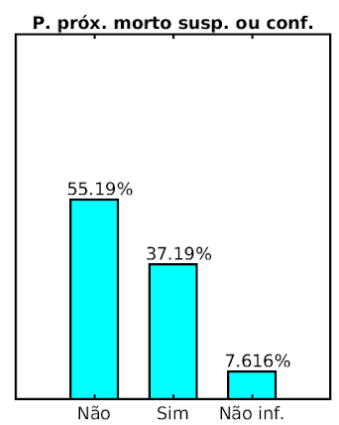

(f)

Figura 29 - Respondentes do ERJ (percepções relatadas)

Os gráficos apresentados na Figura 30 apresentam as informações relatadas pelos respondentes com CPF válido, com relação a se algum parente ou amigo próximo teve (ou tem): suspeita de COVID-19 (a), confirmação de COVID-19 (b) e a suspeita ou confirmação (c); e os casos de falecimento: com suspeita de morte por COVID-19 (d), confirmação de morte por COVID-19 (e) e a suspeita ou confirmação de morte por COVID-19 (f). 


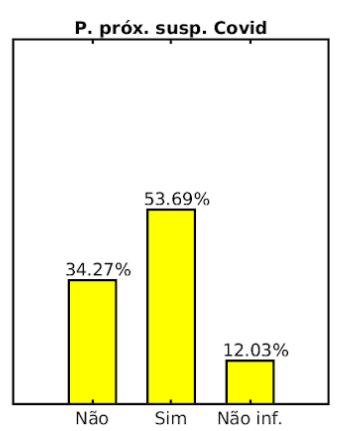

(a)

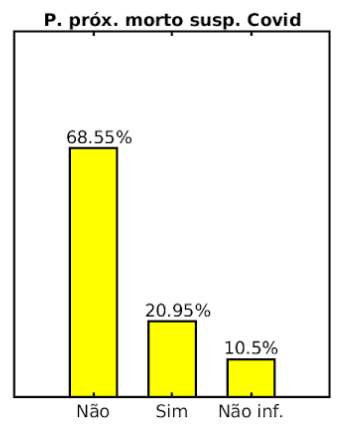

(d)

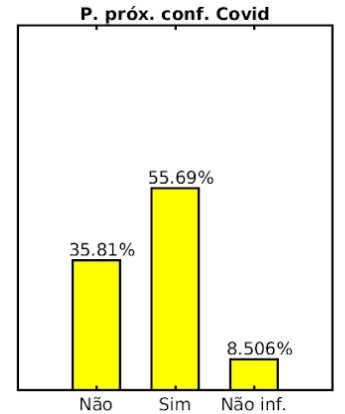

(b)

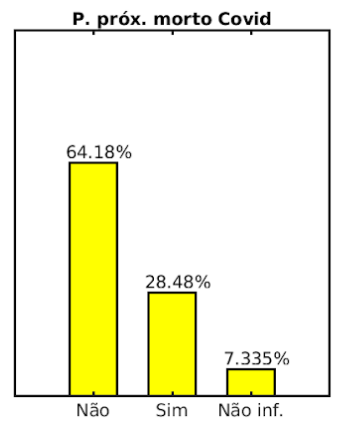

(e)

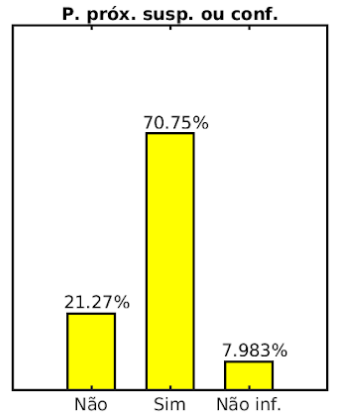

(c)

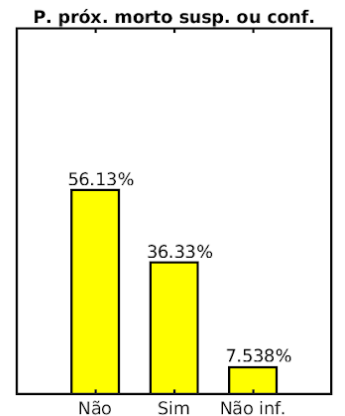

(f)

Figura 30 - Respondentes com CPF válido (percepções relatadas)

Os gráficos apresentados na Figura 31 apresentam as informações relatadas pelos respondentes do estado do Rio de Janeiro e com CPF válido, com relação a se algum parente ou amigo próximo teve (ou tem): suspeita de COVID-19 (a), confirmação de COVID-19 (b) e a suspeita ou confirmação (c); e os casos de falecimento: com suspeita de morte por COVID-19 (d), confirmação de morte por COVID-19 (e) e a suspeita ou confirmação de morte por COVID-19 (f).

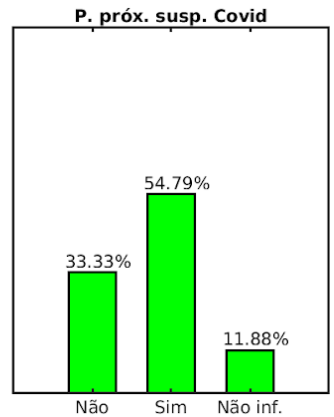

(a)

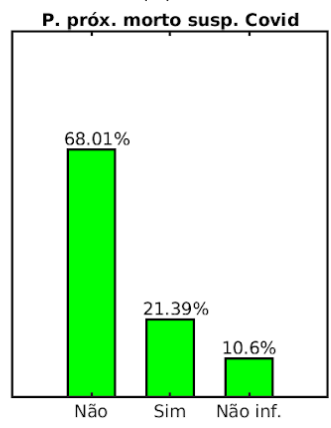

(d)

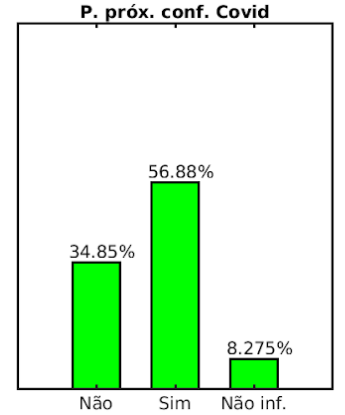

(b)

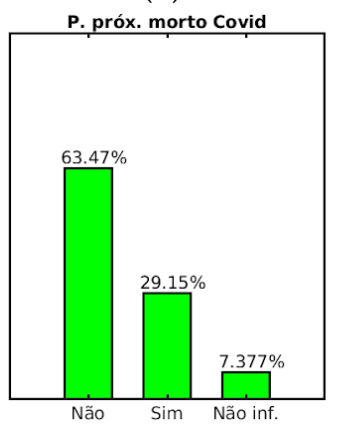

(e)

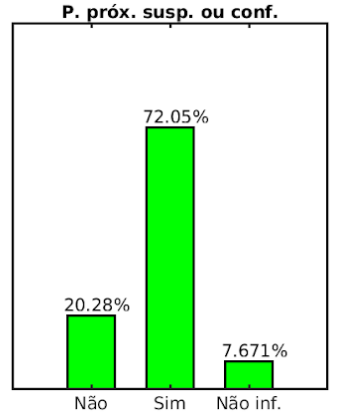

(c)

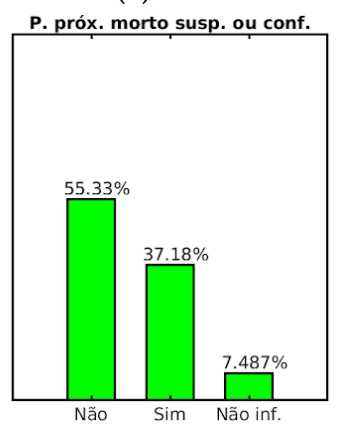

(f)

Figura 31 - Respondentes do ERJ com CPF Válido (percepções relatadas) 
Os gráficos apresentados na Figura 32 apresentam as informações relatadas por respondentes que declararam ser profissionais da área de saúde, com relação a se algum parente ou amigo próximo teve (ou tem): suspeita de COVID-19 (a), confirmação de COVID-19 (b) e a suspeita ou confirmação (c); e os casos de falecimento: com suspeita de morte por COVID-19 (d), confirmação de morte por COVID-19 (e) e a suspeita ou confirmação de morte por COVID-19 (f).

Os gráficos apresentados na Figura 33 apresentam as informações relatadas por respondentes que declaram terem sido testados, com relação a se algum parente ou amigo próximo teve (ou tem): suspeita de COVID-19 (a), confirmação de COVID-19 (b) e a suspeita ou confirmação (c); e os casos de falecimento: com suspeita de morte por COVID-19 (d), confirmação de morte por COVID-19 (e) e a suspeita ou confirmação de morte por COVID-19 (f).

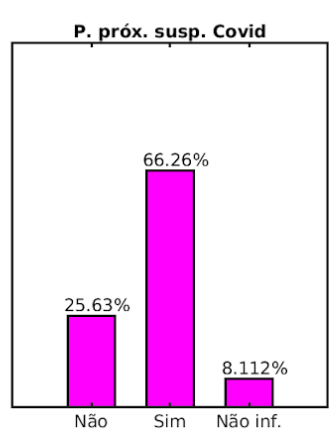

(a)

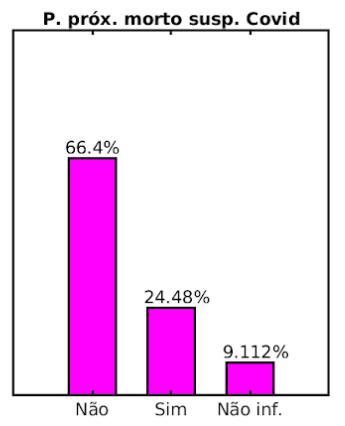

(d)

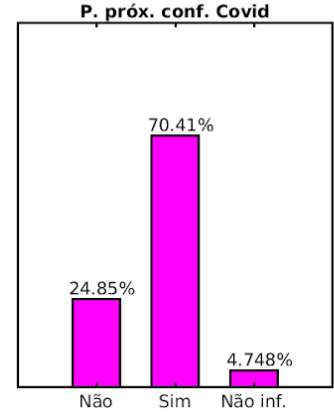

(b)

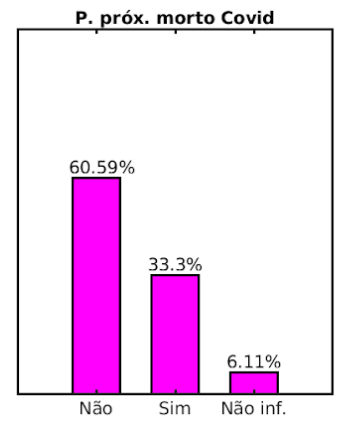

(e)

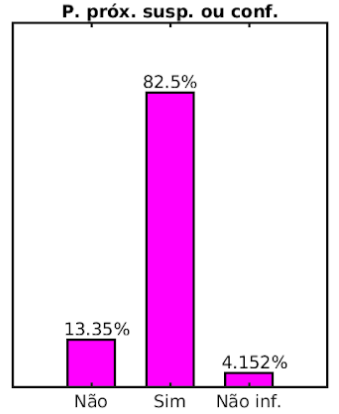

(c)

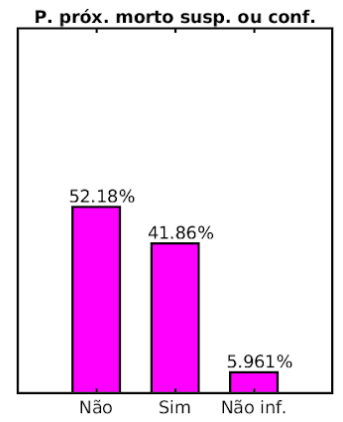

(f)

Figura 32 - Profissionais da Saúde (percepções relatadas)

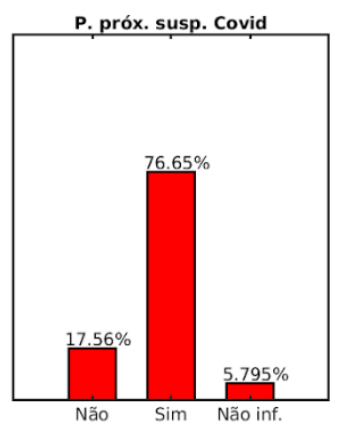

(a)

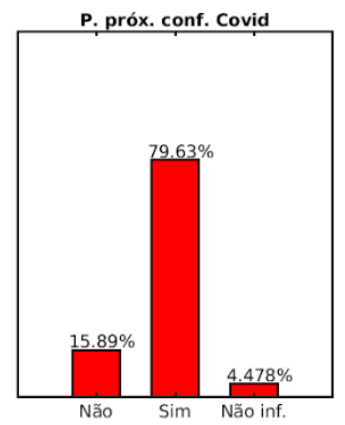

(b)

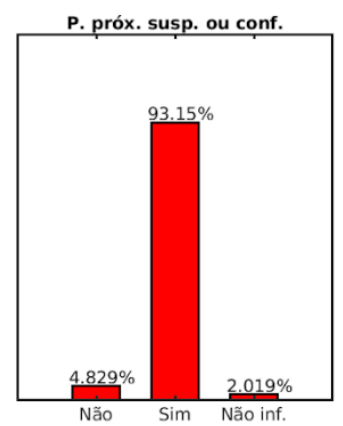

(c) 


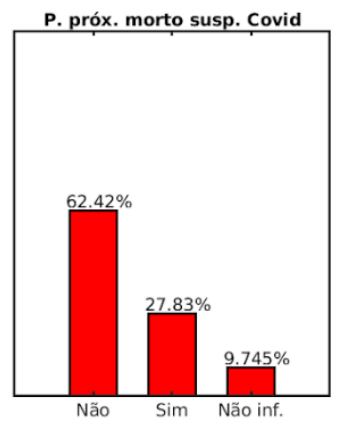

(d)

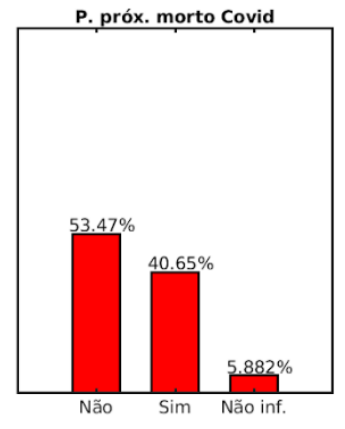

(e)

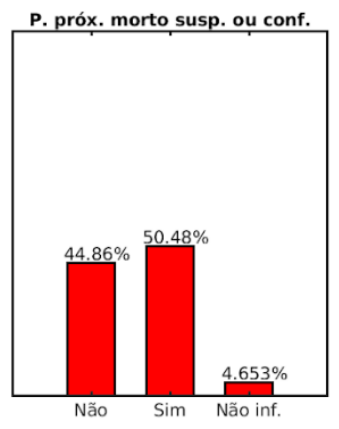

(f)

Figura 33 - Respondentes Testados (percepções relatadas)

As Figuras de 34 a 38 apresentam as proporções dos profissionais de saúde e das atividades informadas pelos respondentes separadas por: todos os respondentes, respondentes do estado do Rio de Janeiro, respondentes com CPF válido, respondentes do estado do Rio de Janeiro e com CPF válido e respondentes que declaram terem sido testados.
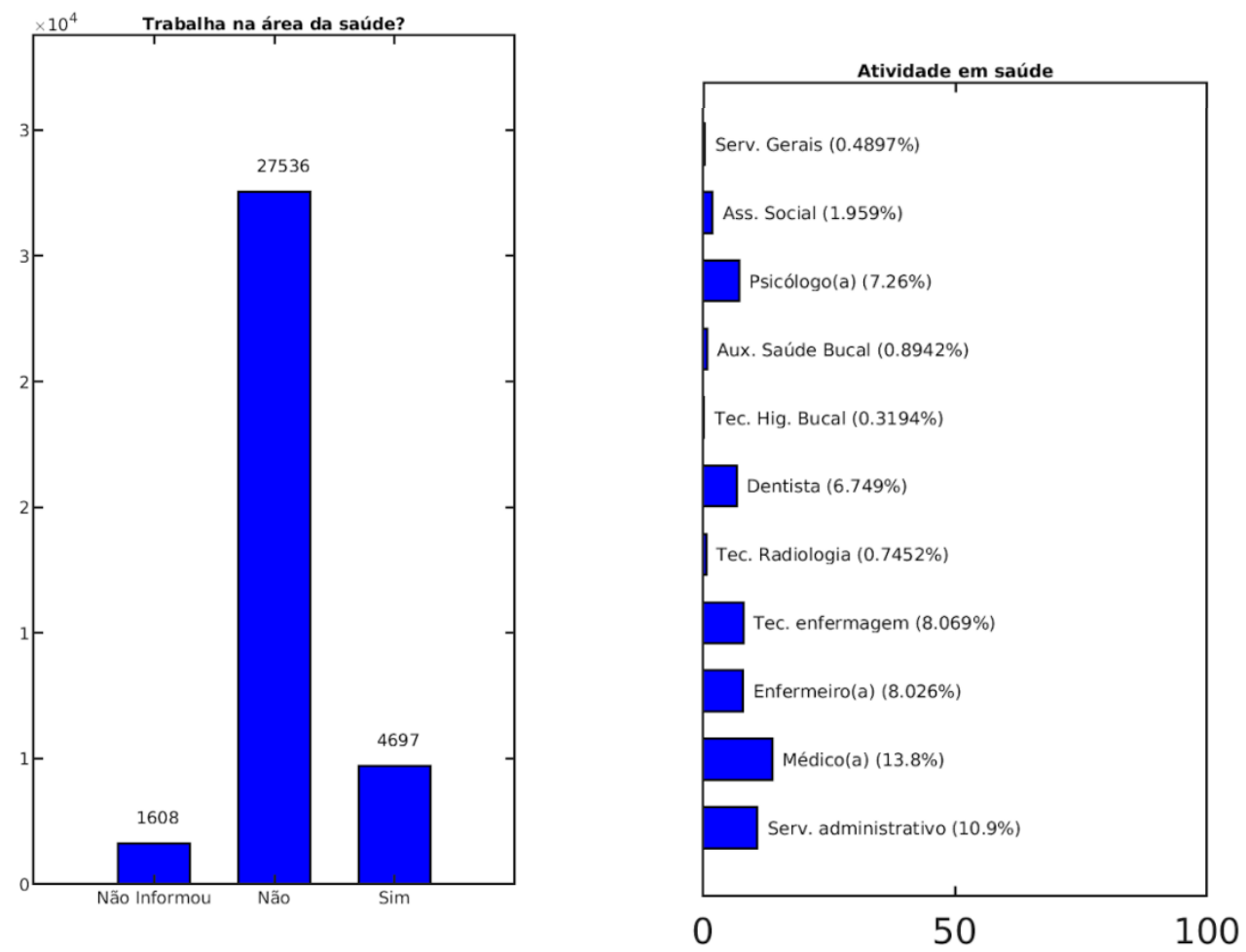

Figura 34 - Todos os Respondentes (atividade em saúde) 

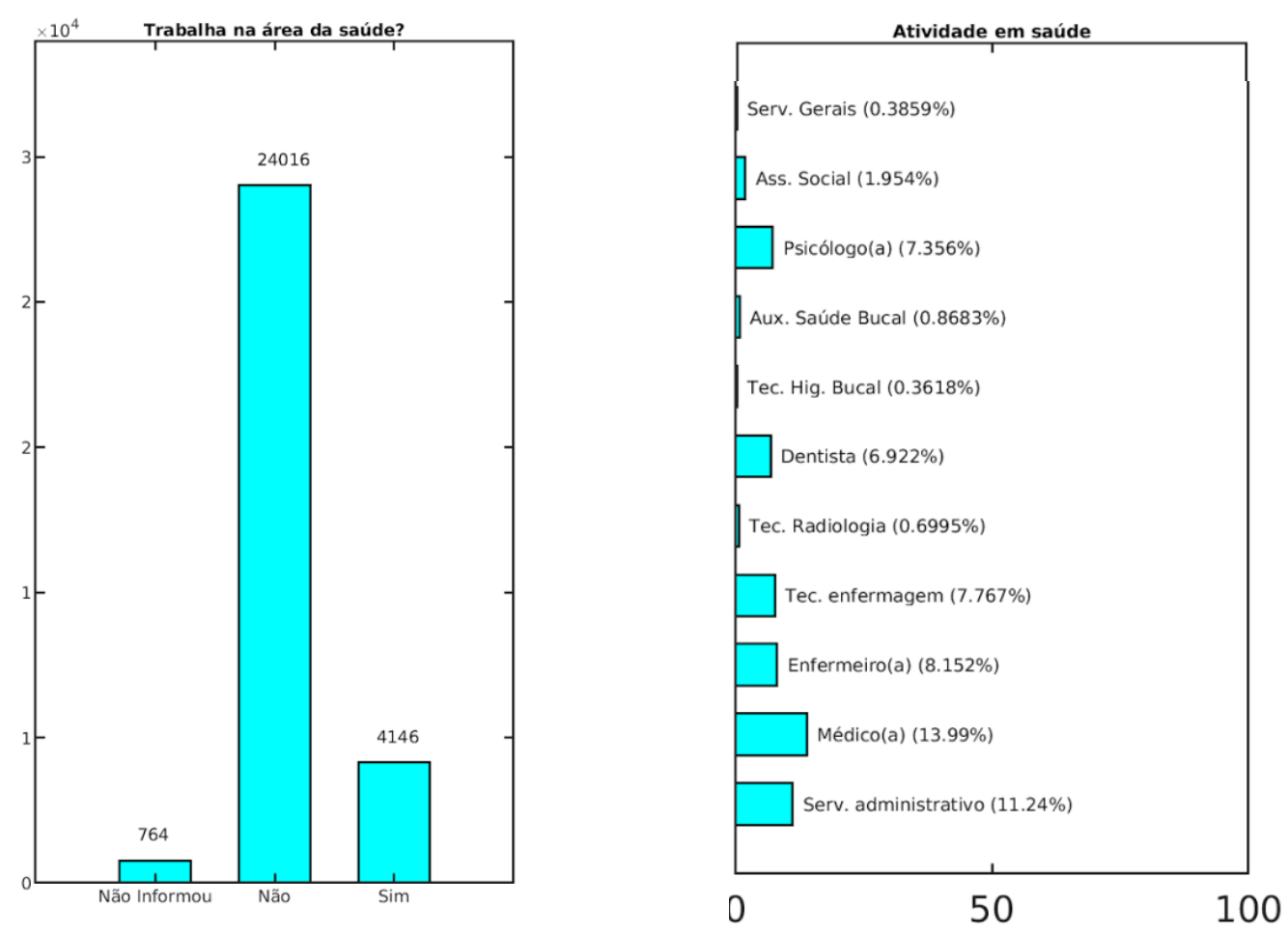

Figura 35 - Respondentes do RJ

(atividade em saúde)
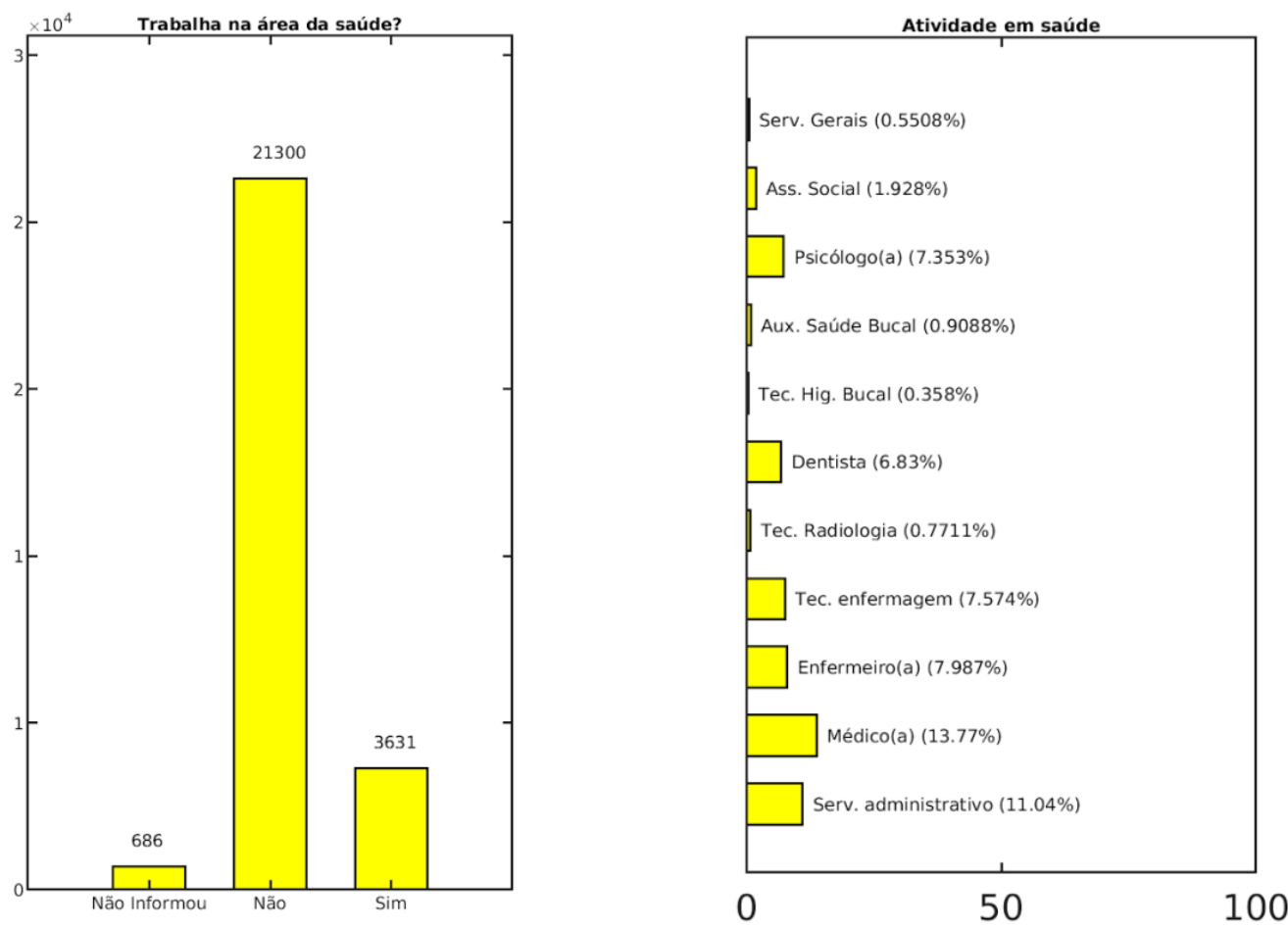

Figura 36 - Respondentes com CPF válido

(atividade em saúde) 

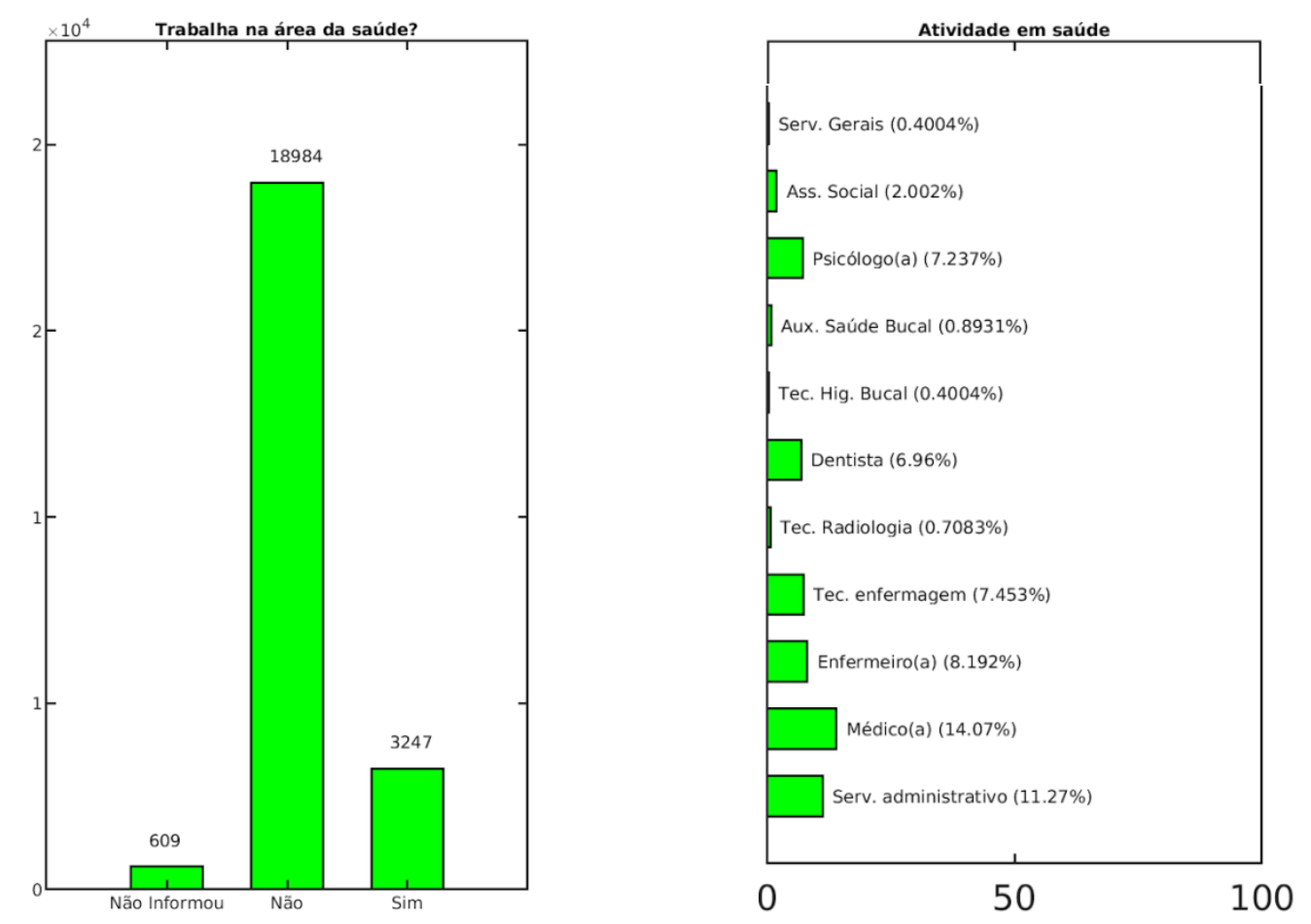

Figura 37 - Respondentes do RJ com CPF Válido (atividade em saúde)
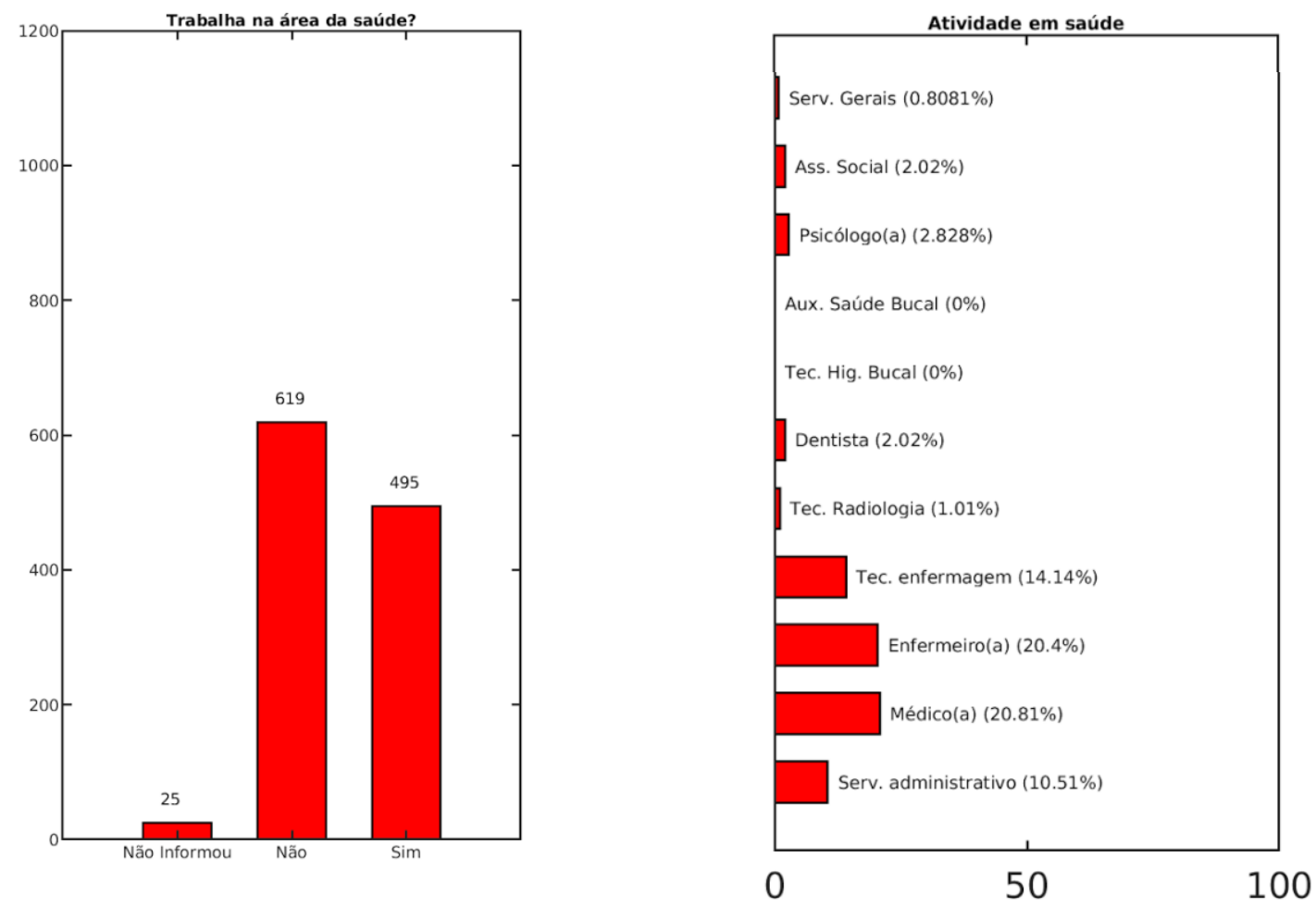

Figura 38 - Respondentes Testados

(atividade em saúde) 


\section{Avaliação da subnotificação}

A partir deste ponto o relatório apresenta informações exclusivamente de respondentes do formulário, cujo CEP pertence ao estado do Rio de Janeiro (85,47\% dos respondentes).

Foram incluídos na avaliação da subnotificação, os respondentes que apresentaram os sintomas definidos pelo MS "Síndrome Gripal" a seguir: febre acompanhada de alguns dos seguintes sintomas: tosse ou coriza ou dor garganta ou dificuldade respiratória, acrescida a ausência de testagem. Assim, foram excluídos desta amostra os respondentes com os sintomas descritos acima que informaram ter procurado atendimento em ambiente de saúde e relataram realização de testagem (PCR ou sorológico).

Assim, serão considerados subnotificados os respondentes que apresentaram os sinais e sintomas, mas não procuraram o ambiente de saúde e também não fizeram qualquer tipo de teste.

Porém, serão considerados como prováveis subnotificados, os respondentes que apresentaram os sinais e sintomas expostos acima, procuraram ambiente de saúde e não foram testados, pois, eventualmente, podem ter sido incluídos em algum tipo de sistema de notificação, em decorrência dos sintomas observados pelos profissionais de saúde que os tenham atendido.

\subsection{Subnotificados e prováveis subnotificados}

Entre os respondentes que possuem os sintomas de síndrome gripal, mas não fizeram testes (PCR ou sorologia), há 3969 (13,72\% em relação aos respondentes do ERJ). Estes respondentes são os que possuem os sintomas definidos pelo MS, e que podem ter sido ou não atendidos em ambiente de saúde.

A Figura 39 apresenta o total de subnotificados somado aos prováveis subnotificados por sexo, sendo um total de 2492 respondentes femininos, 1448 masculinos e 29 não declararam o sexo. A Tabela 1 apresenta a distribuição por faixa etária e sexo para os subnotificados agregados aos prováveis subnotificados.

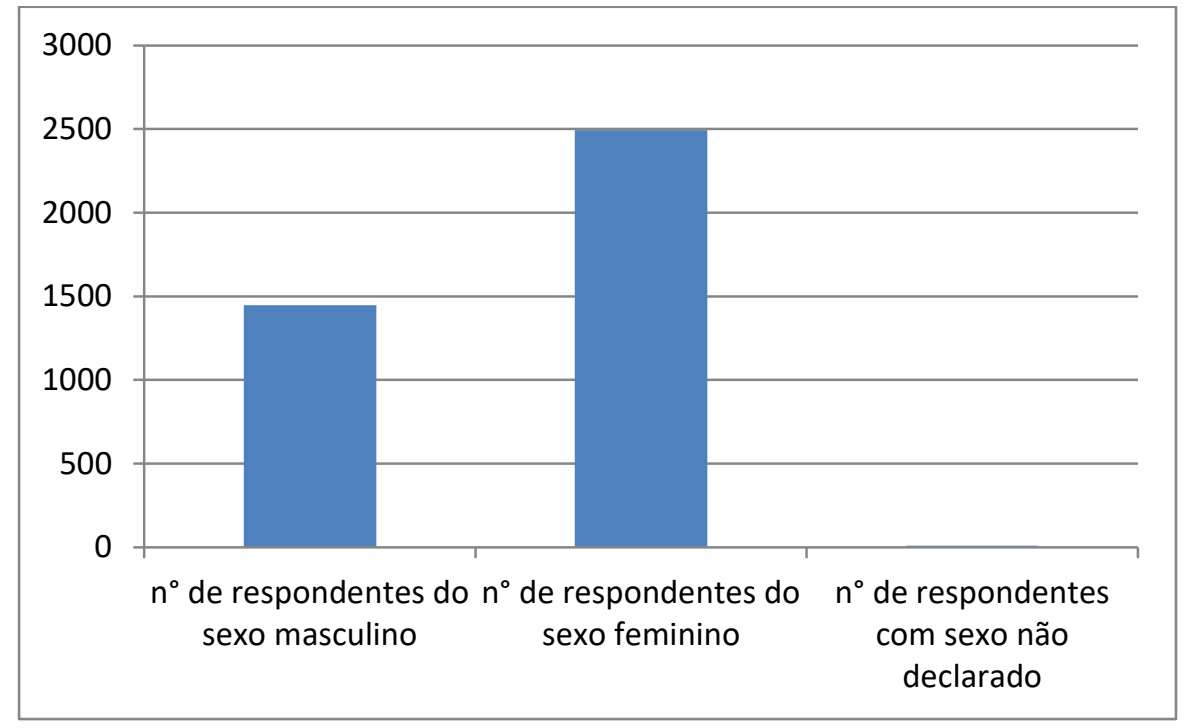

Figura 39 - Total de subnotificados mais prováveis subnotificados com sintomas definidos pelo MS segundo sexo declarado 
Tabela 1 - Distribuição de subnotificados somados aos prováveis subnotificados por faixa de idade e sexo

\begin{tabular}{|c|c|c|c|}
\hline $\begin{array}{c}\text { Faixa de } \\
\text { Idade }\end{array}$ & $\begin{array}{c}\mathrm{n}^{\circ} \text { de respondentes do } \\
\text { sexo masculino }\end{array}$ & $\begin{array}{c}\mathrm{n}^{\circ} \text { de respondentes do } \\
\text { sexo feminino }\end{array}$ & $\begin{array}{c}\mathrm{n}^{\circ} \text { de respondentes } \\
\text { com sexo não } \\
\text { declarado }\end{array}$ \\
\hline $0-9$ & 3 & 5 & 0 \\
\hline $10-19$ & 33 & 56 & 5 \\
\hline $20-29$ & 342 & 534 & 1 \\
\hline $30-39$ & 441 & 693 & 1 \\
\hline $40-49$ & 326 & 592 & 2 \\
\hline $50-59$ & 188 & 383 & 0 \\
\hline $60-69$ & 62 & 138 & 0 \\
\hline $70-79$ & 8 & 17 & 0 \\
\hline $80-89$ & 2 & 4 & 19 \\
\hline $90-99$ & 2 & 0 & 0 \\
\hline $99+$ & 0 & 70 & 0 \\
\hline $\begin{array}{c}\text { Não } \\
\text { Informado }\end{array}$ & 41 & & 0 \\
\hline
\end{tabular}

A Figura 40 mostra gráfico correspondente à Tabela 4. A Tabela 2 e o mapa na Figura 41 indicam os números de subnotificados somados aos prováveis subnotificados por municípios do estado do Rio de Janeiro.

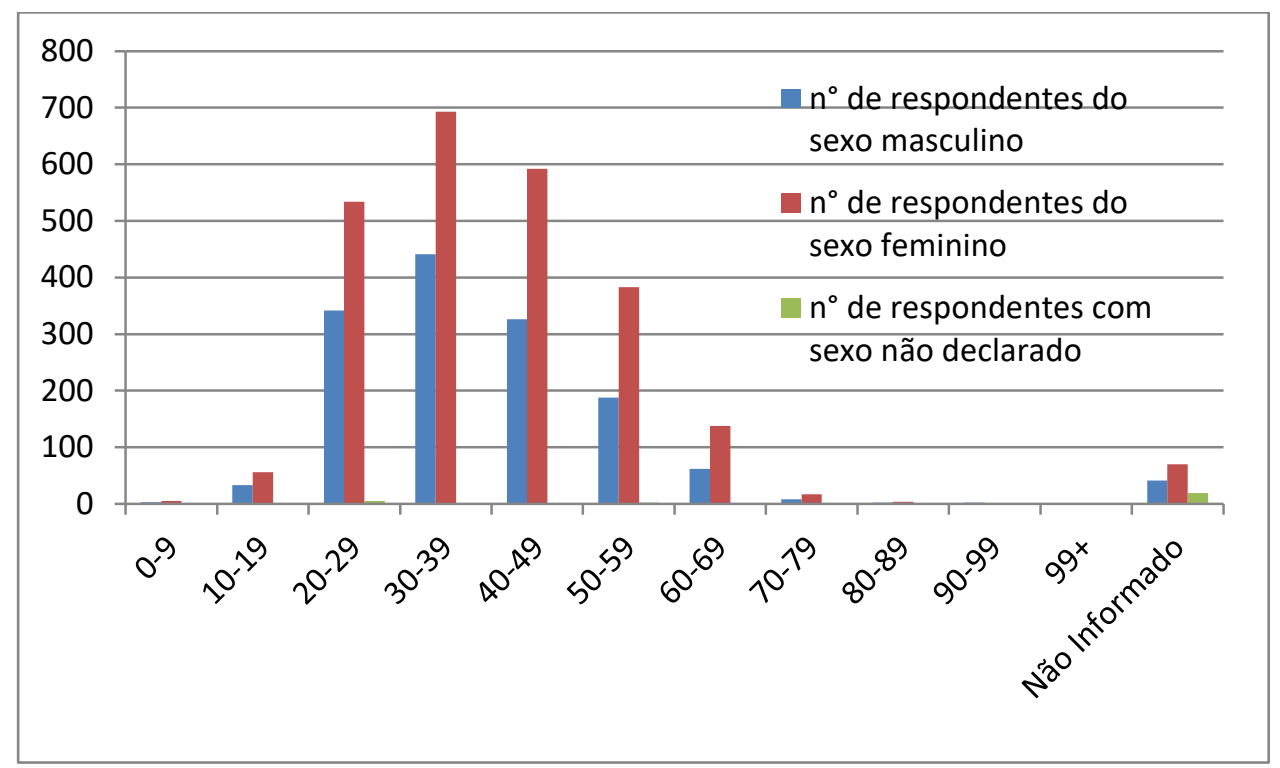

Figura 40 - Distribuição de respondentes por faixa etária e sexo para subnotificados somados aos prováveis subnotificados 
Tabela 2 - Número de subnotificados somados aos prováveis subnotificados por municípios do estado do Rio de Janeiro

\begin{tabular}{|c|c|}
\hline Municípios & Número de indivíduos \\
\hline Angra dos Reis & 12 \\
\hline Araruama & 6 \\
\hline Armação dos Búzios & 2 \\
\hline Arraial do Cabo & 1 \\
\hline Barra Mansa & 6 \\
\hline Barra do Piraí & 6 \\
\hline Belford Roxo & 64 \\
\hline Bom Jesus do Itabapoana & 3 \\
\hline Cabo Frio & 3 \\
\hline Cachoeiras de Macacu & 2 \\
\hline Campos dos Goytacazes & 12 \\
\hline Cantagalo & 1 \\
\hline Carmo & 1 \\
\hline Casimiro de Abreu & 1 \\
\hline Cordeiro & 4 \\
\hline Duque de Caxias & 187 \\
\hline Iguaba Grande & 1 \\
\hline Itaboraí & 21 \\
\hline Itaguaí & 7 \\
\hline Itaperuna & 6 \\
\hline Itatiaia & 2 \\
\hline Japeri & 6 \\
\hline Macaé & 16 \\
\hline Magé & 26 \\
\hline Mangaratiba & 4 \\
\hline Maricá & 5 \\
\hline Mendes & 1 \\
\hline Mesquita & 40 \\
\hline Miguel Pereira & 4 \\
\hline Miracema & 2 \\
\hline Natividade & 1 \\
\hline Nilópolis & 38 \\
\hline Niterói & 145 \\
\hline Nova Friburgo & 12 \\
\hline Nova Iguaçu & 141 \\
\hline Papucaia (Cachoeiras de Macacu) - Povoado & 3 \\
\hline Paracambi & 5 \\
\hline Paraty & 2 \\
\hline Paraíba do Sul & 1 \\
\hline Paty do Alferes & 2 \\
\hline Petrópolis & 20 \\
\hline Pinheiral & 3 \\
\hline
\end{tabular}




\begin{tabular}{|l|c|}
\hline Piraí & 1 \\
\hline Quatis & 1 \\
\hline Queimados & 8 \\
\hline Resende & 8 \\
\hline Rio Bonito & 2864 \\
\hline Rio de Janeiro & 6 \\
\hline Seropédica & 2 \\
\hline Silva Jardim & 2 \\
\hline São Fidélis & 4 \\
\hline São Francisco de Itabapoana & 122 \\
\hline São Gonçalo & 1 \\
\hline São José de Ubá & 87 \\
\hline São João de Meriti & 1 \\
\hline Tanguá & 8 \\
\hline Teresópolis & 5 \\
\hline Três Rios & 3 \\
\hline Valença & 1 \\
\hline Varre-Sai & 4 \\
\hline Vassouras & 10 \\
\hline Volta Redonda & \\
\hline
\end{tabular}




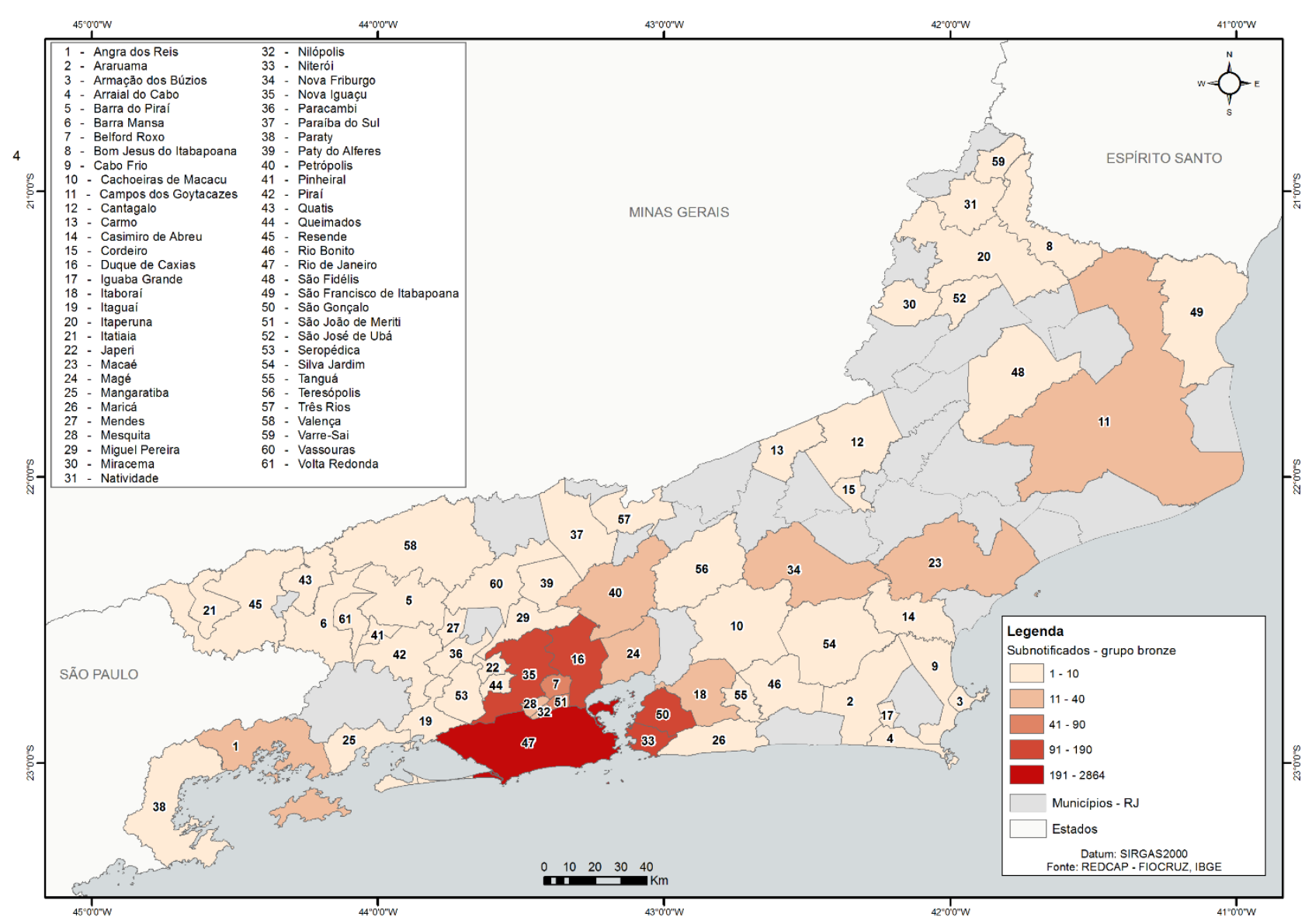

Figura 41 - Mapa com distribuição dos subnotificados somados aos prováveis subnotificados no estado do Rio de Janeiro

\subsection{Subnotificados}

Entre os respondentes que relataram os sinais e sintomas relativos à síndrome gripal, não fizeram testes (PCR ou sorologia) e não foram atendidos em ambiente de saúde estão 2.512 respondentes. Estes foram considerados os verdadeiros subnotificados.

A Figura 42 apresenta o total de subnotificados por sexo, sendo um total de 1.553 respondentes femininos, 937 masculinos e apenas 22 sem sexo declarado. A Tabela 3 apresenta a distribuição por faixa etária e sexo para os subnotificados. 


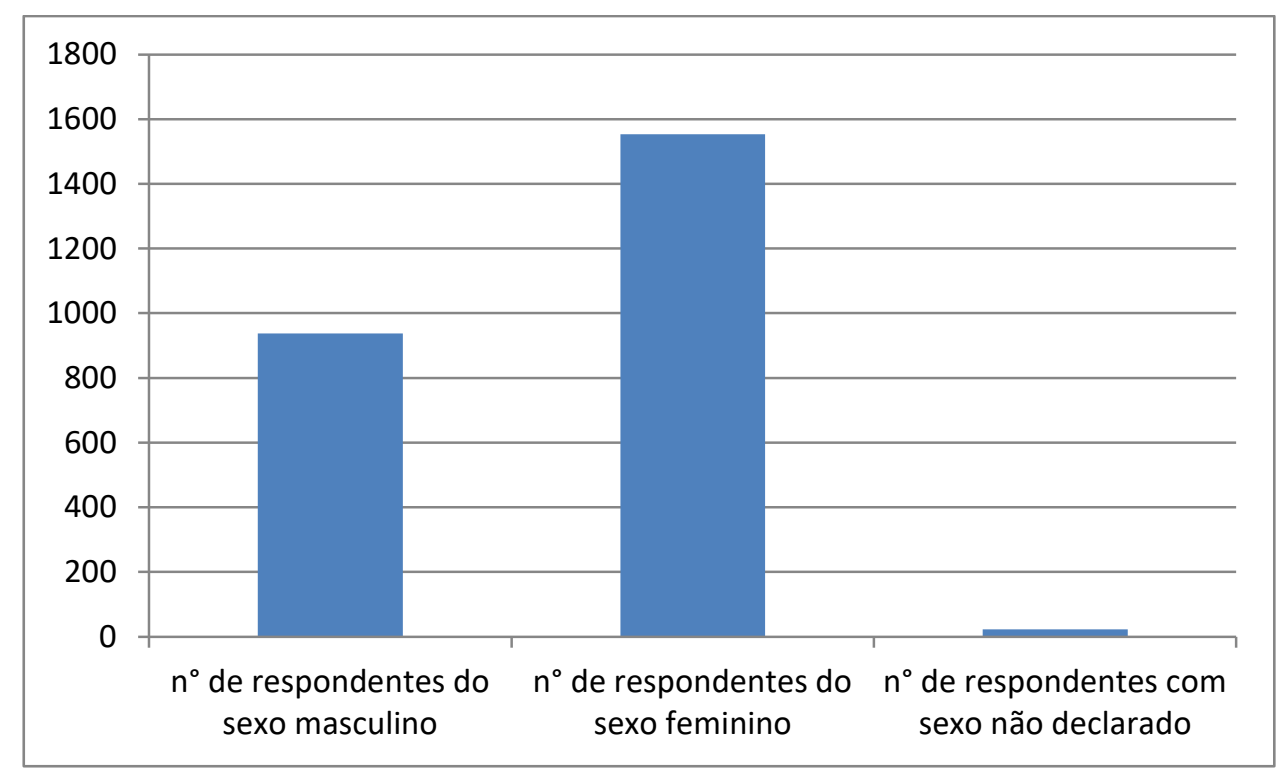

Figura 42 - Total de subnotificados com sintomas definidos pelo MS segundo sexo declarado

Tabela 3 - Distribuição de subnotificados por faixa de idade e sexo

\begin{tabular}{|c|c|c|c|}
\hline $\begin{array}{c}\text { Faixa de } \\
\text { Idade }\end{array}$ & $\begin{array}{c}\mathrm{n}^{\circ} \text { de } \\
\text { respondentes } \\
\text { do sexo } \\
\text { masculino }\end{array}$ & $\begin{array}{c}\mathrm{n}^{\circ} \text { de } \\
\text { respondentes } \\
\text { do sexo } \\
\text { feminino }\end{array}$ & $\begin{array}{c}\mathrm{n}^{\circ} \text { de } \\
\text { respondentes } \\
\text { com sexo não } \\
\text { declarado }\end{array}$ \\
\hline $0-9$ & 2 & 2 & 0 \\
\hline $10-19$ & 27 & 40 & 0 \\
\hline $20-29$ & 249 & 369 & 4 \\
\hline $30-39$ & 285 & 420 & 1 \\
\hline $40-49$ & 201 & 347 & 1 \\
\hline $50-59$ & 107 & 237 & 0 \\
\hline $60-69$ & 36 & 87 & 0 \\
\hline $70-79$ & 3 & 13 & 0 \\
\hline $80-89$ & 2 & 3 & 0 \\
\hline $90-99$ & 1 & 0 & 0 \\
\hline $99+$ & 0 & 0 & 0 \\
\hline $\begin{array}{c}\text { Não } \\
\text { Informado }\end{array}$ & 24 & 35 & 16 \\
\hline
\end{tabular}

A Figura 43 mostra gráfico correspondente à Tabela 3. A Tabela 4 e o mapa na Figura 44 indicam os números de subnotificados por municípios do estado do Rio de Janeiro. 


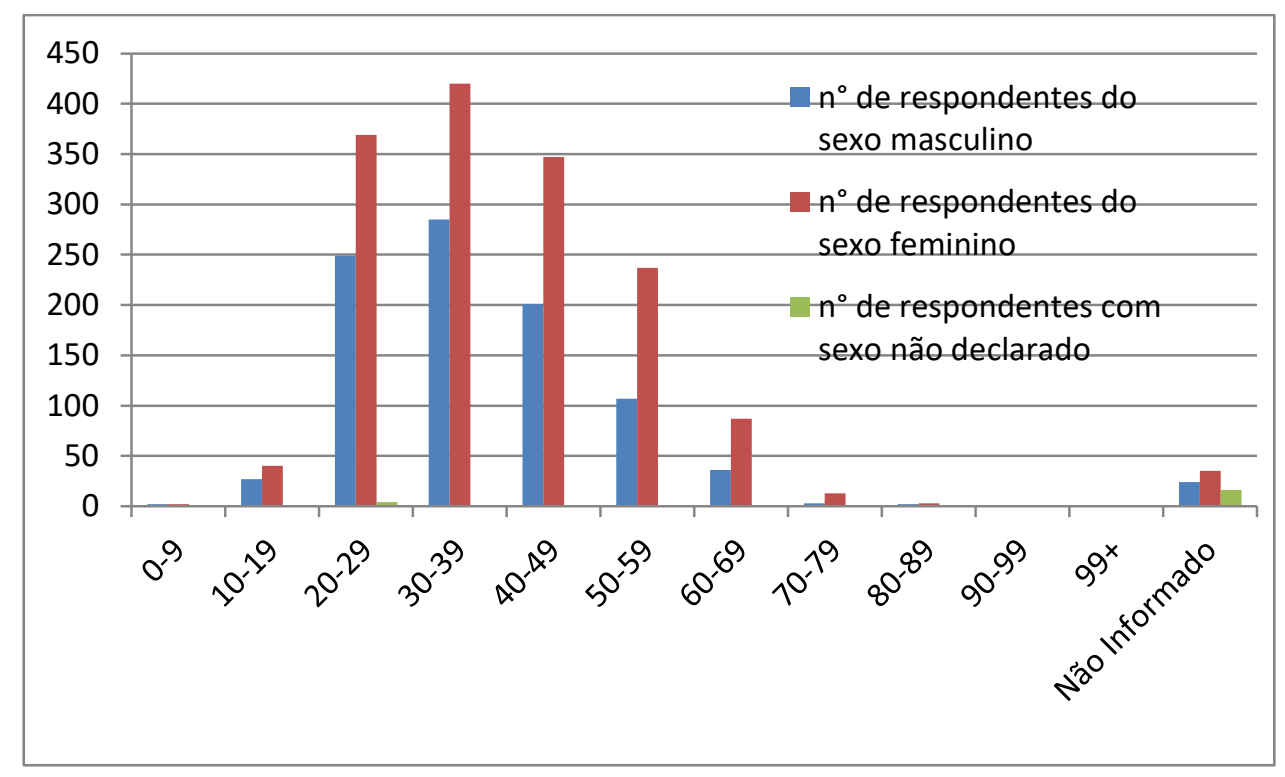

Figura 43 - Distribuição de respondentes por faixa etária e sexo para subnotificados subprata

Tabela 4 - Número de subnotificados por municípios do estado do Rio de Janeiro

\begin{tabular}{|c|c|}
\hline Municípios & Número de indivíduos \\
\hline Angra dos Reis & 4 \\
\hline Araruama & 2 \\
\hline Armação dos Búzios & 2 \\
\hline Arraial do Cabo & 1 \\
\hline Barra Mansa & 5 \\
\hline Barra do Piraí & 5 \\
\hline Belford Roxo & 41 \\
\hline Bom Jesus do Itabapoana & 2 \\
\hline Cabo Frio & 1 \\
\hline Cachoeiras de Macacu & 2 \\
\hline Campos dos Goytacazes & 8 \\
\hline Cantagalo & 1 \\
\hline Carmo & 1 \\
\hline Cordeiro & 1 \\
\hline Duque de Caxias & 104 \\
\hline Iguaba Grande & 1 \\
\hline Itaboraí & 8 \\
\hline Itaguaí & 4 \\
\hline Itaperuna & 4 \\
\hline Itatiaia & 1 \\
\hline Japeri & 6 \\
\hline Macaé & 9 \\
\hline Magé & 16 \\
\hline Mangaratiba & 2 \\
\hline Maricá & 4 \\
\hline Mesquita & 25 \\
\hline Miguel Pereira & 2 \\
\hline
\end{tabular}




\begin{tabular}{|c|c|}
\hline Miracema & 1 \\
\hline Nilópolis & 23 \\
\hline Niterói & 90 \\
\hline Nova Friburgo & 9 \\
\hline Nova Iguaçu & 90 \\
\hline Papucaia (Cachoeiras de Macacu) - Povoado & 2 \\
\hline Paracambi & 3 \\
\hline Paraty & 2 \\
\hline Paty do Alferes & 1 \\
\hline Petrópolis & 14 \\
\hline Pinheiral & 2 \\
\hline Piraí & 1 \\
\hline Quatis & 1 \\
\hline Queimados & 4 \\
\hline Resende & 4 \\
\hline Rio Bonito & 5 \\
\hline Rio de Janeiro & 1830 \\
\hline Seropédica & 6 \\
\hline Silva Jardim & 1 \\
\hline São Fidélis & 1 \\
\hline São Francisco de Itabapoana & 3 \\
\hline São Gonçalo & 73 \\
\hline São João de Meriti & 57 \\
\hline Tanguá & 1 \\
\hline Teresópolis & 7 \\
\hline Três Rios & 5 \\
\hline Valença & 2 \\
\hline Varre-Sai & 1 \\
\hline Vassouras & 4 \\
\hline Volta Redonda & 7 \\
\hline
\end{tabular}




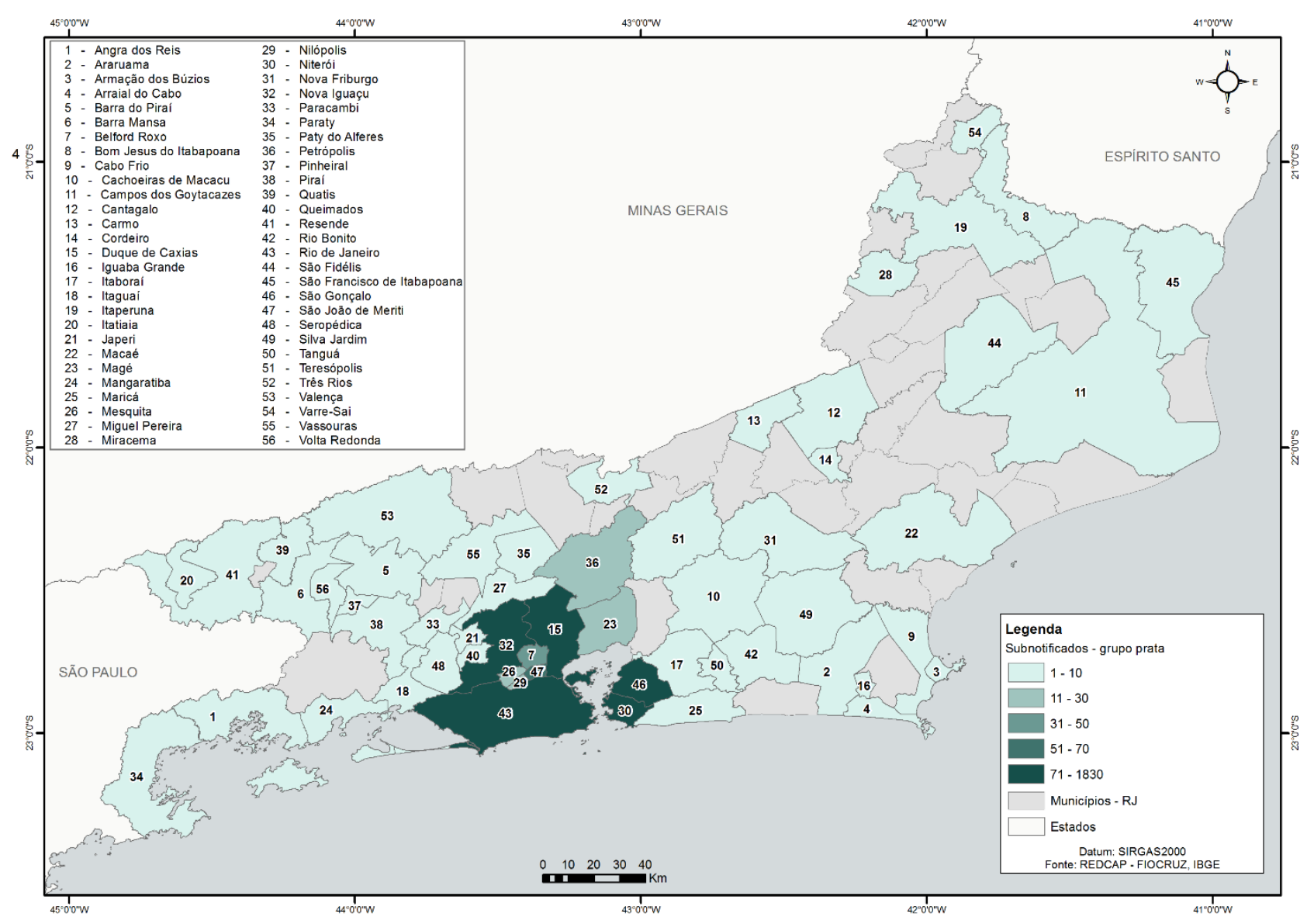

Figura 44 - Mapa com distribuição dos subnotificados no estado do Rio de Janeiro

\subsection{Prováveis subnotificados}

Entre os respondentes que possuem os sinais e sintomas definidos pelo MS como síndrome gripal, não fizeram testes (PCR ou sorologia), mas foram atendidos em ambiente de saúde estão 1.457 respondentes. Este tipo de respondente será denominado provável subnotificado, pois eventualmente pode ter sido notificado no sistema de notificação Notifica no ambiente de saúde.

A Figura 45 exibe o total de prováveis subnotificados por sexo, sendo um total de 939 respondentes femininos, 511 masculinos e 7 sem sexo declarado. A Tabela 5 apresenta a distribuição por faixa etária e sexo. 


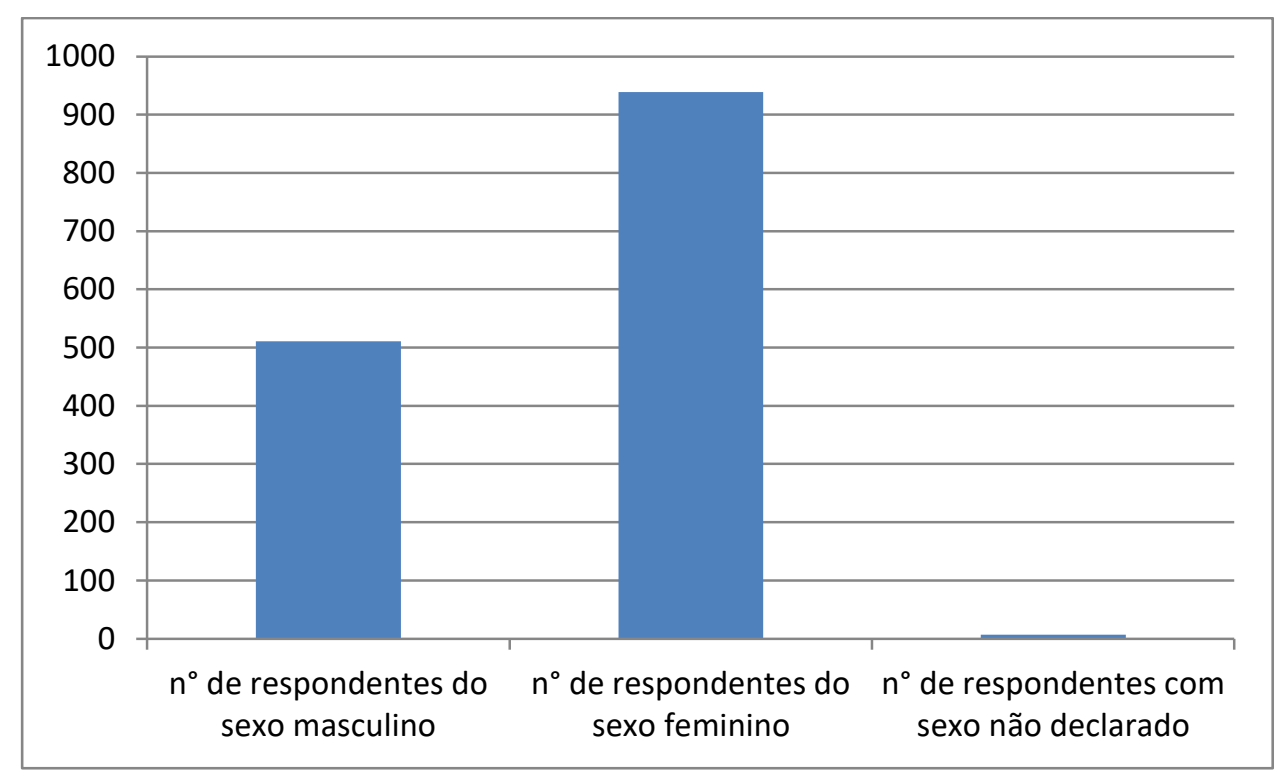

Figura 45 - Total prováveis subnotificados com sintomas definidos pelo MS segundo sexo declarado

Tabela 5 - Distribuição de prováveis subnotificados por faixa de idade e sexo

\begin{tabular}{|c|c|c|c|}
\hline $\begin{array}{c}\text { Faixa de } \\
\text { Idade }\end{array}$ & $\begin{array}{c}\mathrm{n}^{\circ} \text { de respondentes do } \\
\text { sexo masculino }\end{array}$ & $\begin{array}{c}\mathrm{n}^{\circ} \text { de respondentes do } \\
\text { sexo feminino }\end{array}$ & $\begin{array}{c}\mathrm{n}^{\circ} \text { de respondentes } \\
\text { com sexo não declarado }\end{array}$ \\
\hline $0-9$ & 1 & 3 & 0 \\
\hline $10-19$ & 6 & 16 & 0 \\
\hline $20-29$ & 93 & 273 & 0 \\
\hline $30-39$ & 156 & 245 & 1 \\
\hline $40-49$ & 125 & 146 & 1 \\
\hline $50-59$ & 81 & 51 & 0 \\
\hline $60-69$ & 26 & 4 & 0 \\
\hline $70-79$ & 5 & 1 & 0 \\
\hline $80-89$ & 0 & 0 & 3 \\
\hline $90-99$ & 1 & 0 & 0 \\
\hline $99+$ & 0 & 35 & 0 \\
\hline Não & 17 & & 0 \\
Informado & & & \\
\hline
\end{tabular}

A Figura 46 mostra gráfico correspondente à Tabela 5 acima. A Tabela 6 e o mapa na Figura 47 apresentam os números de prováveis subnotificados por municípios do estado do Rio de Janeiro. 


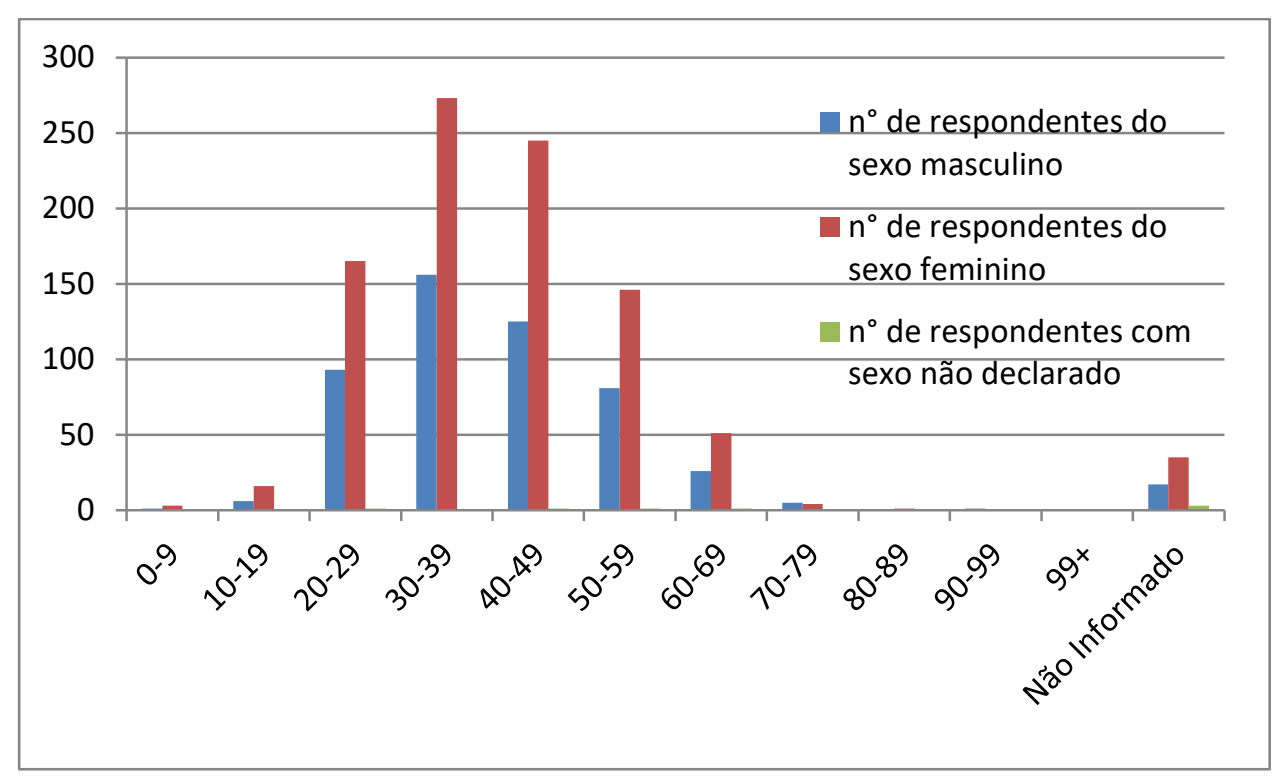

Figura 46 - Distribuição de respondentes por faixa etária e sexo para os prováveis subnotificados

Tabela 6 - Número de prováveis subnotificados por municípios do estado do Rio de Janeiro

\begin{tabular}{|c|c|}
\hline Municípios & $\begin{array}{l}\text { Número de } \\
\text { indivíduos }\end{array}$ \\
\hline Angra dos Reis & 8 \\
\hline Araruama & 4 \\
\hline Barra Mansa & 1 \\
\hline Barra do Piraí & 1 \\
\hline Belford Roxo & 23 \\
\hline Bom Jesus do Itabapoana & 1 \\
\hline Cabo Frio & 2 \\
\hline Campos dos Goytacazes & 4 \\
\hline Casimiro de Abreu & 1 \\
\hline Cordeiro & 3 \\
\hline Duque de Caxias & 83 \\
\hline Itaboraí & 13 \\
\hline Itaguaí & 3 \\
\hline Itaperuna & 2 \\
\hline Itatiaia & 1 \\
\hline Macaé & 7 \\
\hline Magé & 10 \\
\hline Mangaratiba & 2 \\
\hline Maricá & 1 \\
\hline Mendes & 1 \\
\hline Mesquita & 15 \\
\hline Miguel Pereira & 2 \\
\hline Miracema & 1 \\
\hline Natividade & 1 \\
\hline Nilópolis & 15 \\
\hline Niterói & 55 \\
\hline
\end{tabular}




\begin{tabular}{|l|r|}
\hline Nova Friburgo & 3 \\
\hline Nova Iguaçu & 51 \\
\hline Papucaia (Cachoeiras de Macacu) - Povoado & 1 \\
\hline Paracambi & 2 \\
\hline Paraíba do Sul & 1 \\
\hline Paty do Alferes & 1 \\
\hline Petrópolis & 6 \\
\hline Pinheiral & 1 \\
\hline Queimados & 4 \\
\hline Resende & 4 \\
\hline Rio Bonito & 1 \\
\hline Rio de Janeiro & 1034 \\
\hline Silva Jardim & 1 \\
\hline São Fidélis & 1 \\
\hline São Francisco de Itabapoana & 1 \\
\hline São Gonçalo & 49 \\
\hline São José de Ubá & 1 \\
\hline São João de Meriti & 30 \\
\hline Teresópolis & 1 \\
\hline Valença & 1 \\
\hline Volta Redonda & 3 \\
\hline
\end{tabular}

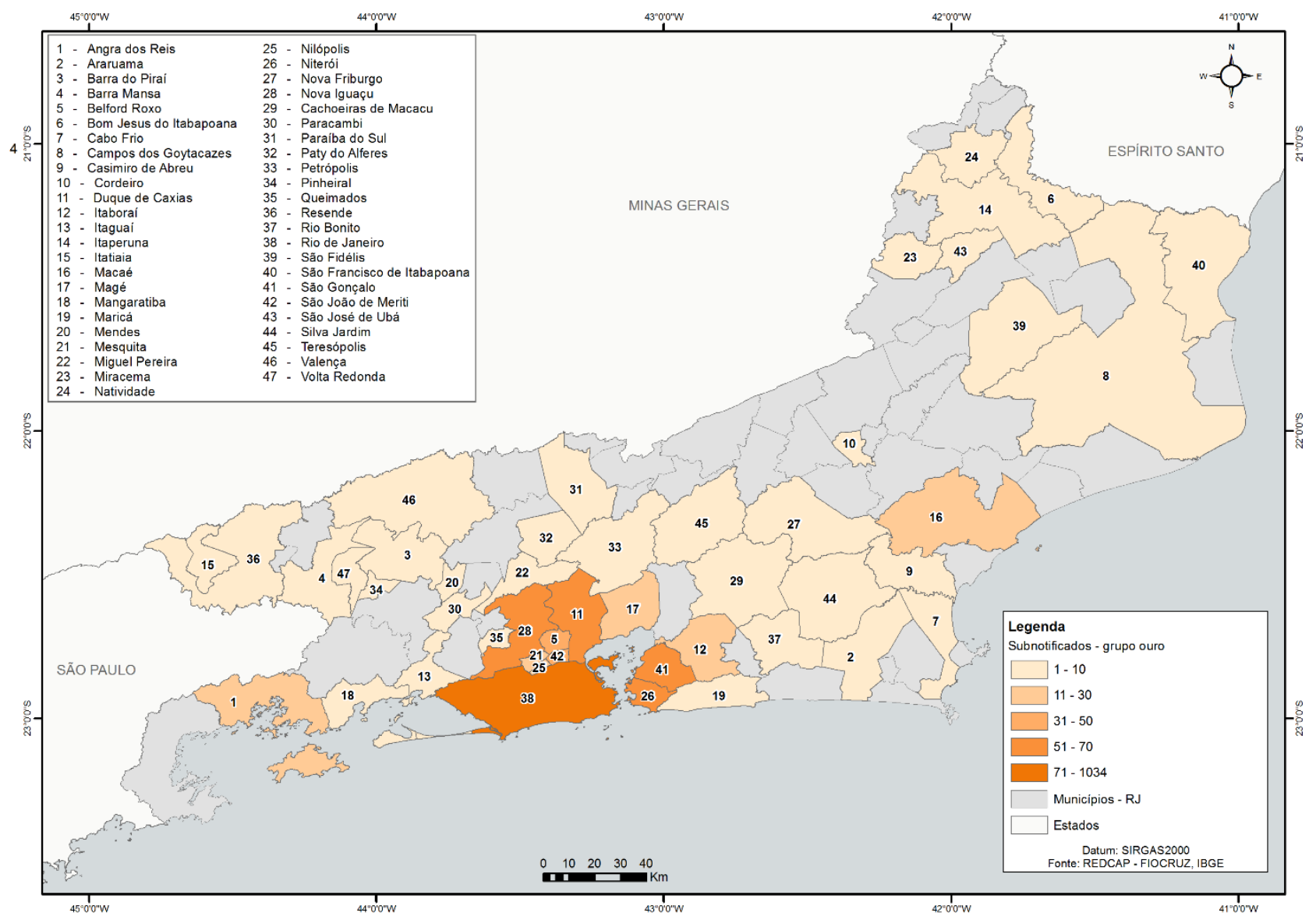

Figura 47 - Mapa com distribuição dos prováveis subnotificados por municípios do estado do Rio de Janeiro 


\section{Conclusão:}

O propósito do questionário foi buscar um método simples, barato e de amplo acesso à população para identificar casos subnotificados, ou seja, pessoas que possam ter tido COVID-19 e não foram atendidas em ambiente de saúde, tendo em vista que não foi possível realizar uma testagem em massa da população.

Assim, a estimativa de casos subnotificados representa a relevância do projeto ao aumentar a informação do quantitativo da população afetada, trazendo a noção da possível magnitude da pandemia de COVID-19 no estado do Rio de Janeiro. Esta projeção fornece subsídios para a adoção de politicas públicas visando, não apenas a prevenção e o controle, como também eventuais ações para mitigação do processo pandêmico, dando diretrizes para uma melhor alocação de recursos de saúde para regiões em que a população possa ter sido mais afetada com a pandemia. Além disso, essa informação pode orientar os gestores de saúde na adoção de medidas de afrouxamento do isolamento social de forma mais segura, já que pode regionalizar tais medidas iniciando-as nos locais que foram mais atingidos pela doença. 
Apêndice A:

Abaixo o questionário completo disponibilizdo no link: https://redcap.icict.fiocruz.br/surveys/index.php?s=WKHKEC8FWE

\section{Subnotificação da COVID-19 no Estado do Rio de Janeiro}

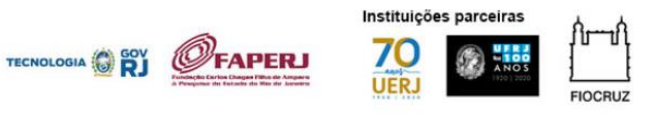

AJUDE NO COMBATE À COVID-19!

Esse questionário tem como objetivo identificar a existência de prováveis casos de subnotificação nos sistemas

de informação, ajudando as ações de prevenção e promoção de saúde pelos órgãos governamentais.

A pesquisa é coordenada pela Subsecretaria de Estado de Ciência, Tecnologia e Inovação (SECTI) e FAPERJ em parceria com a UERJ, UFRJ e FIOCRUZ.

A pesquisa foi aprovada no Comitê de Ética em Pesquisa do Hospital Universitário Pedro Ernesto da UERJ e os pesquisadores comprometem-se a manter o sigilo das informações pessoais, conforme determina a Comissão Nacional de Ética em Pesquisa (CONEP) e a Lei Geral de Proteção de Dados (LGPD). Em caso de dúvidas ou reclamações, por favor entre em contato com (comcienciarjcovid@gmail.com). O preenchimento deste questionário é de livre escolha.

\section{CEP}

(Preencha apenas com os OITO números, sem traço ou barra)

\section{Sexo}

Feminino

Masculino

Prefiro não declarar

\section{Idade (em anos)}


Você trabalha na área de saúde ?

Sim

Não

No último mês, você apresentou algum dos seguintes sintomas ? (Pode marcar mais de uma opção)

$$
\text { * }
$$

$\square$ Febre

$\square$ Tosse

$\square$ Espirro

$\square$ Coriza

$\square$ Dor de garganta

Dor de cabeça

Enjôo

$\checkmark$ Dificuldade de respirar

$\square$ Perda do gosto (paladar)

$\square$ Perda do cheiro (olfato)

$\square$ Diarreia

$\square$ Dor no corpo

$\square$ Nenhum dos sintomas acima

(Se marcar qualquer sintoma e depois marcar Nenhum dos sintomas acima você será avisado que todos os sintomas serão desmarcados)

Qual foi o dia de seu primeiro sintoma (mesmo que aproximado)?

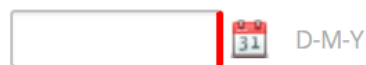

Datas de 01 de março de 2020 até hoje

No último mês, você foi atendido por profissional de saúde?

$\operatorname{Sim}$

Não

\section{$O$ atendimento foi em:}

Ambiente Particular

Ambiente Público

Ambiente Particular e Público 


\section{Você fez teste para saber se estava infectado?}

Sim

Não

Não sei

\section{Que teste(s) você fez para Covid-19?}

(Pode marcar mais de uma opção)

PCR (fiz coleta de secreção do nariz/garganta)

Sorologia (IgG,IgM) (fiz coleta de sangue)

Não sei qual teste fiz

(Se marcar Não sei qual teste fiz,desmarque todos os testes acima)

\section{O resultado do teste foi positivo?}

Sim

Não

Não recebi o resultado

\section{Qual foi o resultado dos testes >} (Pode marcar mais de uma opção)

\section{PCR positivo}

PCR negativo

Sorologia (lgG/lgM) positivo

$\square$ Sorologia (IgG/lgM) negativo

Não sei o resultado

$\square$ Não recebi o resultado

(Se marcar Não sei ou Não recebi o resultado, desmarque todos os resultados acima)

Você tem algum caso suspeito (não testado) de parente ou amigo que tem ou tiveram Covid-19? *

Sim

Não

Não sei informar 
Você tem algum caso de parente ou amigo confirmado por teste que tem ou tiveram Covid-19? *

Sim

Não

Não sei informar

Você tem algum caso suspeito (não testado) de parente ou amigo que morreram pela Covid-19? *

Sim

Não

Não sei informar

Você tem algum caso de parente ou amigo confirmado por teste que morreram pela Covid-19? *

Sim

Não

Não sei informar 